\title{
Petrophysical and mineralogical evolution of weathered crystalline basement in western Uganda: Implications for fluid transfer and storage
}

\author{
B. Walter, Y. Geraud, D. Bartier, J.-M. Kluska, M. Diraison, \\ C. Morlot, and F. Raisson
}

\begin{abstract}
The effects of weathering on the mineralogical and petro- physical properties of the western Uganda Archaean crys- talline basement were investigated using outcrop samples. This study aimed to characterize a typical composite vertical weathering profile by the integration of data from samples with variable degree of alteration, ranging from fresh to com- pletely weathered. A detailed description of samples is pro- posed, using different observation methods (e.g., $\mathrm{x}$-ray computed tomography scanning and quantitative evaluation of minerals by scanning electron microscopy analysis system). Petrophysical analyses were carried out to fully describe the porous network of the samples (e.g., mercury porosimetry [f] and permeability [k] measurements). A geometric factor reported in the litera- ture is also used to describe the variable complexity of the porous network through the weathering profile. This multimethod study revealed two distinct domains in the weathering profile, separated by a sharp property transition. The lower part of the profile is characterized by dominant planar pore structures and represents a high transfer zone for fluid cir- culation (f $£ 8 \%-10 \%$; $\mathrm{k} £ 500 \mathrm{md}$ ). The upper part of the profile is characterized by high clay content and dominant vacuole-shaped matrix porosity. This represents a high fluid storage zone ( $\mathrm{f} » 30 \% ; \mathrm{k} £ 1 \mathrm{~d}$ ). Both parts are locally pre- served from complete clay plugging by hydrodynamic drainage, resulting from a long-term geomorphic evolution. In the case of preservation of such a composite weathering profile after basement burial in a sedimentary basin with hydrocarbon potential, these domains may represent a significant area for petroleum exploration. Properties described in this study indicate that the weathered basement in such a basin can act as a large reservoir for hydrocarbons or as a favorable mi- gration zone at the interface between the basement and the sedimentary cover. Finally, several proxies are proposed to help for the recognition of these two domains from cutting analyses and well logging.
\end{abstract}

\section{INTRODUCTION}

Oil and gas accumulation in basement rocks is generally consid- ered as one of the most unusual resource systems. Nevertheless, over the last several decades, hundreds of basement reser- voirs have been discovered around the world, and many of these produce high levels of hydrocarbons (Petford and McCaffrey, 2003; Sircar, 2004; Trice, 2014). Such hydrocarbon basement reservoirs are mainly located within extensional tectonic settings (e.g., rifting system and margin setting) and commonly correspond to structural highs, fed by sedimentary source rocks (Gutmanis, 2009; Gutmanis et al., 2015). Such a structural geometry can be developed by different elements: fault-bounded basement blocks (e.g., horst structure and tilted or uploaded block), buried pa- leohills, or intrusive igneous bodies (Landes et al., 1960; P'an, 1982; Parnell, 1988; Younes et al., 1998; Gutmanis, 2009). Fracturing and weathering have been recognized as the two processes that develop storage properties in crystalline (e.g., Parnell, 1988; Cuong and Warren, 2009), metamorphic (e.g., Salah and Alsharhan, 1998; Younes et al., 1998), or volcanic rocks (e.g., Wang et al., 2011). These studies highlighted the impor- tance of reservoirs associated with weathering and paleosurfaces of basement formations that were developed by exposure to meteoric agents. Fresh basement rocks, especially crystalline rocks, generally have low fluid transfer and storage properties, but weathering processes with primary mineral phases leaching and cracking can lead to the 
development of significant secondary porosity (e.g., Angerer et al., 2011a; Jamtveit et al., 2011; Dubois et al., 2014).

Basement rocks, especially crystalline rocks, with their weathered horizons and underlying fractured bedrocks can harbor significant water supplies that reflect the factor of al- teration on reservoir development (e.g., Lachassagne et al., 2011). Supergene alteration processes are particularly well recognized in Africa, with basement aquifers characterized by a typical weathering profile and hydraulic vertical heteroge- neities (Figure 1) (e.g., Chilton and Smith-Carington, 1984; Acworth, 1987; Wright, 1992; Chilton and Foster, 1995; Taylor and Howard, 2000; Deyassa et al., 2014). Thus, weathering induces substantial changes in the mineralogical composition and petrophysical properties of the basement, with important implications for hydraulic properties.

In the framework of geophysical prospecting for hydro- carbon basement reservoirs, recently published studies have focused mainly on fault and fracture characterizations of potential basement reservoirs, based on knowledge and skills acquired during decades of work on more conventional frac- tured reservoirs (e.g., Luthi, 2005; Angerer et al., 2011b; Alai et al., 2014; Murray and Montgomery, 2014; Slightam, 2014). As the factor of weathering in hydrocarbon basement reser- voirs is recognized, detailed mineralogical and petrophysical characterization of analogous samples could help future studies for the definition of reservoir properties and identifi- cation of reservoir units by core logging, cutting analysis, or seismic imaging.

Given the implications that basement rock weathering has on hydrocarbon and water resources, this study aims to charac- terize the petrophysical and mineralogical evolution of crys- talline rocks affected by supergene alteration in hot and humid climates. Various alteration facies of crystalline basement rocks were collected in a single area in western Uganda, near Lake Albert, which is known for its hydrocarbon resource potential. Several sediment and basement oil seeps along the shore have been described (e.g., Dou et al., 2010; Karp et al., 2012; Abeinomugisha and Kasande, 2013).

Based on a macroscopic criteria classification, this study presents a description of the mineralogical and petrophysical evolution between different weathering grade samples. The rock property variations were characterized using differ- ent sample observation methods (optical microscopy, quantitative evaluation of minerals by scanning electron microscopy [QEMSCAN] analysis system, scanning electron microscopy [SEM], and x-ray computed tomography [CT]) scanner), x-ray diffraction (XRD) analysis, and petrophysical mea- surements (porosity, permeability, density, and acoustic wave propagation velocity). These methods are described in further detail below, as is the geological setting of the study area. This work emphasizes the development of different pore net- work geometries with variable degree of weathering, high- lighted by high-resolution imaging. This composite profile presents a specific petrophysical evolution, especially unusual permeability patterns that contrast with those of previous studies (e.g., Acworth, 1987; Chilton and Foster, 1995; Dewandel et al., 2006). The new complementary multiple data sets obtained allowed us to discuss the evolution of key petrophysical and mineralogical parameters with weathering and estimate such a reservoir volume.

\section{GEOLOGICAL SETTING OF THE WEATHERED BASEMENT IN WESTERN UGANDA}

\section{Geological Setting of the Study Area}

Western Uganda is crosscut by the northern segment of the western branch of the East African rift system (EARS), consisting of a complex graben system more than $700 \mathrm{~km}$ (435 mi) long, composed of several basins progressively trending from north- northeast-south-southwest to northeast-southwest, from Lake Kivu to north Lake Albert (Chorowicz, 2005). This graben system developed since the Miocene, with rare occurrences of volcanic events propagating through Archaean and Proterozoic mag- matic and metamorphic basement rocks (Ebinger, 1989; Schlueter, 2006). Older basement rocks were formed during a series of Archaean tectonic phases, between 3 and 2.6 Ga. Further tectonic events occurred during the Proterozoic, developing a se- ries of orogenic belts that cut across the Archaean basement complex. The Mesoproterozoic Kibaran orogenic belt unconformably overlies Archaean rocks and the Paleoproterozoic Ubedian orogenic belt and follows along a dominant northeast trend in the region (Hepworth and Macdonald, 1966; Leggo, 1974; Aanyu and Koehn, 2011). The Mio- cene rift locus is controlled by these preexisting Proterozoic lithospheric suture belts, acting as a mechanical weakness 
zone between the two stable Precambrian Tanzania and Congo cratons (e.g., Ebinger, 1989; Link et al., 2010; Katumwehe et al., 2015).

The present study targets the Archaean felsic granitoid and gneiss units located on the eastern shore of Lake Albert (Figure 2), along the northeast- trending rift-bounding Toro-Bunyoro fault system (Chorowicz, 2005). In this area, several rock units with similar granitoid texture and composition have been identified. The felsic granulite of the Karuma complex corresponding to high-grade vaguely banded metamorphic gneiss with low anhydrous Fe-Mg sili- cate content and granitic to granodioritic composition was dated circa 2991 - 9 Ma (Westerhof et al., 2014). Tonalite-trondhjemite-granodiorite (TTG) gneiss was also identified in this area, with variable granitoid composition (granite and TTG) and texture. Ages of circa 2584-18, 2637 - 16, and 2611 - 14 Ma for similar TTG gneiss were found farther south in the foothills of the Rwenzori Mountains, obtained by U-Pb age determinations of zircon cores (Link et al., 2010).

\section{Review of the Weathering Development and Applications of the Basement in Western Uganda}

Taylor and Howard $(1998,2000)$ proposed a tecto- nogeomorphic model of the weathering evolution of the Ugandan basement since the late Paleozoic. This model is valid for warm and humid climates and is based on an alternation of two geomorphic processes, depending on the tectonic activity in the area. Deep in situ weathering of the basement rocks occurs during long periods of tectonic quiescence, whereas stripping occurs with tectonic uplift and local base-level

readjustment. Thus, the basement alteration and its related hydrodynamic properties result from longterm evolution of geomorphic tectonically controlled cycles. From the late Paleozoic glaciation to the midCretaceous, during a long period of tectonic quies- cence, the climate became warmer and more humid and the Precambrian basement underwent deep weathering through most of the Mesozoic (Taylor and Howard, 2000). Between mid-Cretaceous and the early Miocene, uplift associated with the South Atlantic opening ended the weathering phase and started a period of stripping of the basement rocks. From the Miocene, the basement underwent a new deep weathering phase that remains active to the present day, except in areas adjacent to the EARS in western Uganda. In this part of the country, the rifting modified the local base level, leading to a new cycle of stripping, which is still active according to the pro- posed tectonogeomorphic model.

Studies of the alteration surfaces of the Ugandan basement, especially in the Lake Albert area, have been carried out by many authors in the last few decades (e.g., Bishop and Trendall, 1966; Straaten, 1977, and references therein). Along the eastern side of the lake, two different lateritic surfaces reflecting a complex interplay between rift faulting and geo- morphic processes are identified (Straaten, 1977). The older prerift surface characterized by deep zones of intensively weathered basement is probably equivalent to the upper Mesozoic "African surface" described by King et al. (1972). The younger lateritic surface is developed at the top of the older surface but also at the top of some rift sediment in the basin, despite the stripping phase proposed by Taylor and Howard's (2000) model in this area of the EARS.

Different possible applications using the deep weathered basement properties of the Ugandan Precambrian rocks (e.g., clay deposits and aquifers) resulted in several mineralogical or hydrodynamic investigations (e.g., Batte et al., 2008). Aquifers and associated hydrodynamic properties of the weathered basement formations and the underlying fractured bedrock are related to weathering processes. These develop vertical weathering profiles of 30-100 m ( 100-300 ft $)$ average thickness, where the moderately to intensively weathered layers are a storage factor and the underlying fractured layers are a transfer or flow path factor (Taylor and Howard, 2000; Nyende et al., 2014). In eastern Uganda, McFarlane (1983) investigated an approximately 40 -m-thick ( $\sim 130$-ft- thick) weathered profile, located in a heteroge- neous basement, which is predominantly composed of para-amphibolite rocks. A progressive evolution in the mineral composition can be identified with al- teration. Quartz, kaolinite, and iron hydroxide are the dominant mineralogical components of the highly weathered facies. In central Uganda, Nyakairu et al. (2002) investigated several clay deposits that developed from weathering of various Precambrian basement lithologies (e.g., metasediments, schists, undifferentiated gneisses, and granites). All the clay 
samples analyzed consisted mainly of iron-rich kao- linite. The vertical weathering profiles tended to have similar mineralogical and hydrodynamic character- istics over a wide variety of basement rock types (Nyende et al., 2014).

\section{SAMPLING AND METHODS}

\section{Sampling}

Although vertical weathering profiles are described for the area, no complete profile could be sampled at a single location. Because of the poor morphological exposure and total profile thickness (several tens to hundreds of meters [or feet]), no complete cross section of weathered basement could be identified. However, the different alteration facies composing the weathering profile defined in Figure 1 were observed at different locations along road cuts or in small quarries (Figure 2). Because these locations correspond to two similar lithological units of the crystalline basement, i.e., Archaean felsic granulitic and orthogneiss according to the geological map (Virransalo et al., 2012; Westerhof et al., 2014), the different samples collected allowed the compilation of a vertical weathered profile from fresh basement, through moderately weathered rocks (i.e., saprock), to intensively weathered rocks (i.e., saprolite). Only minor petrological differences are observed between samples, and a similar fresh protolith is assumed for all specimens. Slight differences in the petrology of the Precambrian basement are suggested as being insignificant relative to geomorphologic weathering processes and final alteration products (Taylor and Howard, 2000). Transitions between the different stages of weathering are generally gradational. Macroscopic features like (dis)coloration, rock texture, or relative strength can be used to separate the weathering stages into grades. Such weathering grade classification is commonly used in engineering ge- ology (reviewed in Dearman, 1995; Ehlen, 2002; Price, 2009). Thirteen rock samples were collected at the locations described above and taken to be represen- tative of all the different stages of an in situ vertical supergene weathering profile. Samples vary in color with weathering, from gray-yellow to red, associated with changes in texture and stiffness (Figure 3). It is noteworthy that the development of weathering is generally controlled by the geometry of brittle structures present in the rock mass (Figure 3E). The samples were classified according to macroscopic criteria and the weathering terminology of Ehlen (2002) and Price (2009) with five different facies (Table 1). Facies I corresponds to the unweathered fresh rocks; facies II corresponds to the rocks with slight changes in color where several discontinuities (fractures, cracks) are developed, which may contain secondary fillings; and facies III is represented by weaker but still coherent rocks, with changes in color. More discontinuities with alteration fillings are developed, and partial opening of grain boundaries occurs; facies IV corresponds to considerably weak- ened rocks and friable materials with separation of grains because of mineral leaching. Original rock texture is still mainly preserved; finally, facies $\mathrm{V}$ is represented by completely weathered and friable

rocks in which the original texture is partly preserved. According to these criteria, sample classification and location coordinates are given in Table 2. However, no facies IV samples were identified on the field.

\section{Analytical Methods and Procedures}

The mineralogical variation throughout the weathered profile was studied with a broad data set, using different two-dimensional (2-D) and three-dimensional (3-D) and quantitative observation methods: optical microscopy, SEM, QEMSCAN imaging and anal-ysis, XRD analysis, and x-ray CT scanning.

Thin sections of samples were analyzed using the FEI QEMSCAN analysis system at the Total Centre Scientifique Total Jean Fe'ger. This system is a non- destructive SEM method, using energy dispersive xray spectroscopy to produce 2-D mineralogical mapsofsamples.Quantitativemineralogicalmaps of full thin sections $\left(\sim 4-5 \mathrm{~cm}^{2}\right)$ were acquired at $15 \mathrm{kV}$ (acquisition time $\sim 1 \mathrm{hr}$ per sample) at a resolution of $50 \mathrm{~mm}$ and up to 3000 counts per pixel.

The XRD whole rock patterns were recorded at room temperature with a D2 Phaser Bruker diffractometer equipped with a LYNXEYE detector, using CuKa radiation, $30 \mathrm{kV}$ accelerating voltage and10mAcurrent(locatedattheMuse'umNational d'Histoire Naturelle, Centre de Recherche sur la pale' obiodiversite' et les pale' oenvironnements [UMR CNRS]). The x-ray patterns were recorded on bulk rock samples, using a scan step of $0.02^{\circ} 2 \mathrm{q}$, exposure time of $0.4 \mathrm{~s}, 2 \mathrm{q}$ minimum $=3^{\circ}$ to $2 \mathrm{q}$ maximum $=75^{\circ}$. 
Semiquantitative mineral contents were estimated using EVAC software coupled to the International Centre for Diffraction Data PDF-2 database. Clay mineralogy was recorded from $2 \mathrm{q}$ of $2^{\circ}-40^{\circ}$ with a step size of $0.02^{\circ} 2 \mathrm{q}$ over $0.6 \mathrm{~s}$. Semiquantitative analysis of the relative abundance of clay minerals in the less than $2 \mathrm{~mm}$ fraction was done using the method described by Holtzapffel (1985).

Samples were observed using a Phoenix Nanotom x-ray CT scanner located at the University of Lorraine, UMR CNRS 7359 GeoRessources. This tool provides a nondestructive technique to reconstruct 3-D images of solid samples (e.g., Ge' raud et al., 1993; Soete et al., 2015). Virtual cross sections were extracted from the volume to observe the internal structure (voids, inclusions, and porosity) and mineralogical composition (phases with different x-ray attenuation) of the sample. Scans were performed at $90 \mathrm{keV}$ and $125 \mathrm{~mA}$, with a voxel size of $5 \mathrm{~mm}^{3}$ to optimize the contrast between different mineral phases and porosity. Porosity and mineralogical image analyses were obtained using the Vg studio and Avizo softwares.

Different petrophysical analyses were performed at the University of Lorraine in the UMR CNRS 7359 GeoRessources laboratory. Porosity and pore space parameters were determined using mercury intrusion porosimetry (MIP). The MIP was carried out with a Micromeritics AutoPore IV 9500 device, using 220 $\mathrm{MPa}$ as maximum mercury pressure. This gave in- formation about pores with a threshold diameter between $350 \mathrm{~mm}$ and $5 \mathrm{~nm}$. The MIP method, initially proposed by Washburn (1921), is based on the principle that a nonwetting fluid penetrates simple-shaped voids (e.g., tubes and cracks) if the injection pressure is high enough to exceed the capillarity forces. This method provides a wide range of information, e.g., the total pore volume and pore size distribution, or ap- parent and skeletal sample densities (Van Brakel, 1975; Vavra et al., 1992). However, it is important to note that given sizes are not systematically the pore sizes but threshold values controlling pore access (i.e., pore throat size). Analyses were performed on small samples of $2-3 \mathrm{~cm}^{3}$ dried at $60^{\circ} \mathrm{C}$ for $24 \mathrm{hr}$ to remove humidity from the pore network.

Rock permeability was measured using a gas permeameter with nitrogen as an ideal incompress- ible fluid, based on Darcy's law (Scheidegger, 1974; Miguel and Serrenho, 2007). Gas was injected through the samples at various imposed pressures, and the flow rate was measured on drilled cylinders with

a 2.3-cm (0.91-in.) diameter and 2.2-cm (0.87-in.) length. However, the highly weathered samples could not be drilled. Therefore, the cylindrical shape was reproduced by molding resin around small pieces of samples. Because of its high viscosity, this resin does not penetrate the sample at ambient pressure, and measurements can be performed after cutting off the two extremities of the cylinder to have the rock sample accessible at the surface of the cylinder base and top. The two apparent rock areas for each sample were precisely calculated using image-processing soft- ware. Permeability of the samples was obtained using the Klinkenberg equation, which corrects the over- estimated permeability measurements caused by the Klinkenberg effect induced by the phenomenon of gas slippage along porous network walls (Klinkenberg, 1941; Debschu“ tz et al., 1989).

The elastic wave velocity measurements through samples were carried out using a Pundit II (Proceq Lt) device. The analyses were conducted in the labora- tory either on small rock cubes, between 5 and $10 \mathrm{~cm}$ ( 2 and 4 in.), or on parallel smooth surfaces of samples that were too friable to cut. A weighted P-wave velocity was given for each sample. This nondestructive method has been used in many studies to analyze relationships between the elastic wave velocity and different con- trolling factors such as density, porosity, mineralogical composition, grain size, and shape (e.g., Birch, 1960; Babus`ka, 1984; Babus`ka and Pros, 1984; Gaviglio, 1989; Yasar and Erdogan, 2004; Stane k et al., 2013).

Gas pycnometry was used to determine the skeletal density (i.e., density of the solid phases) of the sample rocks. Measurements were carried out by constant-volume gas pycnometry, using a Micro- meritics AccuPyc II 1340 helium pycnometer at a temperature of $23^{\circ} \mathrm{C}$, with a pressure of $1310 \mathrm{hPa}$

3 and a testing chamber of $3.5 \mathrm{~cm}$.

RESULTS

Evolution of the Mineralogical Properties 


\section{through the Weathering Profile}

\section{Optical Microscopic Observations}

The low-grade weathered samples (facies I and II) are considered to be representative of fresh rock or basal saprock horizons. These samples have the same main mineralogical content. They are characterized by a granitic composition, with a subequigranular texture and grain size of 0.5-3 mm. Major components in thin sections are quartz $(\sim 36 \%-41 \%)$, microcline $(\sim 22 \%-26 \%)$, and plagioclase $(\sim 28 \%-33 \%)$, and minor components $(\sim 5 \%)$ are biotite, illite, chlorite, and mus- covite, where proportions are given by QEMSCAN analysis of several thin sections (Figure 4A-C). Ac- cessory minerals consist of subhedral to anhedral apatite, zircon, and opaque minerals. These samples show no clear grain shape preferential orientation even if mica and chlorite stacks are generally slightly elongated. Plastic deformation still occurred according to the quartz and feldspar mineral undulose extinc- tion and grain shape suggesting that recrystallization was by grain boundary migration. Because these ductile strain features are also observed within the various weathered facies composing the upper units of the profile, the ductile deformation in the Archaean felsic gneiss occurred prior to the supergene alter- ation phase. Brittle deformation is observed with intramineral and transmineral cracks and intra- mineral microcracks. A preferential orientation of this network is generally visible, suggesting that these planar discontinuities have been induced by tectonic stresses. Feldspar microcracks are well organized and developed according to the orientation of crystalline structures like twinning planes. All of these structures represent a crackdominated low-porosity network, and secondary clay material can be locally present as small infillings of such cracks. Sericitization of pla- gioclase is well developed, but this does not affect alkali feldspars, which are relatively fresh. Alteration of biotite is also observed, and chlorite is generally present as mica and chlorite stacks ( $\$ 70 \%$ biotite- dominated) occurring at biotite edges and cleavages (Figure 4C). Moreover, QEMSCAN analysis shows several examples of biotite totally transformed into illite, even if the biotite optical characteristics are still visible with the polarized microscope on the altered minerals. Biotite and chlorite are also slightly oxidized, showing some leaching of iron phases.

The intermediately weathered samples (facies III) are considered to be representative of the saprock horizon (Figure 1). These samples underwent rock fragmentation with development of low-dipping joints of millimeter-scale opening and centimeter- scale spacing (Figure 4A, B, D). This loss of co- hesion and textural change relative to the bedrock facies was described as weathering brecciation by

Angerer et al. (2011a). At the thin section scale, secondary clays, especially illite, developed along the joints (Figure 4B, D). Nevertheless, between these open structures, the mass rock displays no significant mineralogical differences compared with facies I and II. These samples show a clear increase of microcrack and crack densities and therefore of sec- ondary fracture porosity.

Higher-grade weathered samples (facies V) are considered to be representative of the middle to top saprolite horizon (Figure 1). These completely weathered samples are characterized by strong clay and iron oxide and hydroxide enrichment. Major components are quartz $(\sim 30 \%)$, microcline $(\sim 30 \%)$, and kaolinite $(\sim 30 \%)$. Plagioclase and mica stacks observed on facies I, II, and III are almost totally kaolinitized, whereas K-feldspar is moderately weathered (Figure 4A, B, E). These samples are characterized by a massive increase in transmineral and intramineral crack densities, with consistent microlaminated infillings of more or less iron-rich kao- linite and hydroxide, developing a kataalteromorphic texture. This texture describes major mineral shape and rock volume modifications in three directions, caused by different processes such as chemical weath- ering, fracturing, and swelling of expandable sec- ondary minerals (Delvigne, 1998). In these samples, primary grains are destroyed, and rock volume is highly modified because of massive fracture in- fillings. Hematite can also be locally present as infilling. Some residual pore spaces in the fracture infilling are preserved, but the major apparent porosity is matrix porosity, resulting from the chemical weathering (leaching and dissolution) of the primary mineral phases (e.g., feldspar) and the development of secondary minerals with intermineral connected voids. Plagioclase organized minute residues are observed, which produce significant in- tramineral pore structures whose regular alignments are related to the distribution of intramineral microcracks, cleavages, and twinning planes (Delvigne, 1998) (Figure 4F). Secondary kaolinite formed according to a botryo-alteromorphic texture also pro- duces matrix porosity. Clusters of stacked side-byside automorphic crystallites of kaolinite developed, in- terspersed by many small interstitial interconnected voids (Delvigne, 1998). An iron-rich weathering mixture with a breccia-like texture is also 
observed, composed of primary quartz and feldspar clasts, and an iron-rich secondary hydroxide and clay coating, with some vacuole-shaped pores. Thus, porosity of the completely weathered samples (facies V) appears to be matrix-dominated.

\section{X-Ray Diffraction Analyses}

The XRD analyses carried out on bulk powder highlight the mineralogy of the weathering grades observed in thin sections (Table 3). Bedrock and intermediately samples (facies I, II, and III) are mainly composed of quartz, microcline, and plagioclase; micas are scarce. Higher-grade weathered samples (facies V) are totally different, with the occurrence of kaolinite and the disappearance of plagioclase. Thus, from facies I to $\mathrm{V}$, semiquantitative analyses show a relative en- richment of quartz and kaolinite and a loss of feldspar minerals. In contrast to microscopic observations, which show iron oxides and hydroxides, XRD whole patterns did not display any clear oxide peak. Iron-rich zones could be present as an amorphous gel or as very poorly crystallized content, possibly iron (III) oxide- hydroxide ferrihydrite.

The XRD analyses of oriented less than $2 \mathrm{~mm}$ fractions were performed on the same material (Figure 5, Table 3). The clay fraction of the low-grade weathered samples (facies I and II) is dominated by micaceous minerals, smectite, illite, and mixed- layered smectite-chlorite (Figure 5A). Mica appears to be mainly trioctahedral as indicated by a very weak 5-A reflection. No rational or chaotic series of peaks are identified, so Newmod modelization (Reynolds, 1985) was not very useful to determine a modeled mixedlayered smectite-chlorite material. Similarly, the method of Hower (1981) is not appropriate for the determination of the smectite content. The mixed- layer mineral is only identified by a broad reflection ${ }^{\circ} \mathrm{a}$ widening $(\sim 15.2 \mathrm{~A})$ of the base of the smectite peak in ethylene glycol solvated slides. However, reflections are consistent with a trichlorite-trismectite (85:15) 2- glycol mixed layer. Contrary to observations of thin sections, no discrete chlorite is recognized by a rational glycol mixed layer. Contrary to observations of thin sections, no discrete chlorite is recognized by a rational series of peaks at 14.3, $7.10,4.73$, and 3.54 A. This suggests that the chlorite-like mineral observed under the polarizing microscope corresponds to trioctahedral mixed layers. Thus, the mixed-layer minerals could indicate a retrograde alteration product of chlorite. The chlorite alteration to supergene smectite was already postulated by Mellini et al. (1991) in the deepest structural complex of the Betic Cordillera (Spain) and by Nieto et al. (1994) in the Malaguide complex in Sierra de Espufia (Spain). Mellini et al. (1991) proposed that a rapid uplift, induced by the thinning of the tectonic pile by erosion and ex- tensional postmetamorphic processes, is the cause of the chlorite alteration in the Nevado-Filabride complex (Spain). In the same way, Vazquez et al. (2007) described dense fracture networks adjacent to fault structures in the Iberian Variscan chain that localize the development of a retrograde association with kaolin group minerals and smectite through epizonal paragenesis. As in Nieto et al. (1994) for the Malaguide slate or Doval et al. (2012) for a paleoweathering profile in central Spain, transmineral cracks and intramineral microcracks are assumed to have paved the way for fluid transport, favoring biotite alteration into chlorite and trioctahedral mixed layers under low- temperature conditions. Finally, the alteration of biotite as an origin for a swelling mixed layered mineral was evoked by Bjorlykke (1975) during the weathering of granitic Precambrian gneiss in Uganda near Kampala. In intermediately weathered samples (facies III), the clay fraction is dominated by smectite and kaolin group minerals (Figure 5B). The broad peak at approximately $7.2 \mathrm{~A}$ could indicate the presence of poorly crystalline kaolinite and halloysite $(7 \mathrm{~A})$. The response to ethylene glycol solvation involves a de- crease in peak height of the peak at approximately 7.2 A and an increase in peak height of the peak at approximately 3.58 A. Compared with facies I and II, facies III samples are characterized by the disappearance of the chloritesmectite mixed layer, the decrease of smectite and development of the kaolin group minerals. This higher degree of weathering could be related to the clear increase in fracture porosity, which allows increased fluid circulation. The completely weathered samples (facies V) are characterized by a kaolinite-dominant clay fraction (Figure 5C). In these samples, the 7.2-A reflection is stronger and sharper, indicating the presence of well-crystallized kaolinite, and a small quantity of halloysite $(7 \mathrm{~A})$ is also certainly present. According to thin section observation, kao- linite occurs as plagioclase and mica replacements, which have been observed in many studies (Ahn and Peacor, 1987, and references therein). Kaolinite forms after smectite in humid climates, and its formation takes a long time ( $>100$ k.y.; Bronger, 2007). The low amounts of mica, absence of smectite, and high amounts of kaolinite indicate an intense weathering process: more active solution drainage, more oxi- dizing conditions, and so more leaching of mobile elements. 


\section{X-Ray Computed Tomography Analyses}

Three different weathered samples (ug13.06, ug13.18, and ug13.39) were investigated using an x-ray CT scanner. The gray color scale of the images allows a relative comparison of different components with various radiological densities of samples. The lowest- density elements, i.e., darker ones, correspond to voids, and a description of the pore morphology is thus possible. The highest-density elements, i.e., the brighter ones, are considered to be iron-rich oxides (e.g., he- matite, density of $5.3 \mathrm{~g} \mathrm{~cm}^{-3}$; Smyth and McCormick, 1995). No other mineral phases with similar density, except a few zircons (density of $4.65 \mathrm{~g}$ $\mathrm{cm}^{-3}$ ), were identified in the different samples by microscope- based observations.

On the basis of gray level thresholds selected manually, different extreme density elements (i.e., lowest and highest density values) were isolated to reconstruct 3-D images of these elements (porosity and ironrich oxides). The proportions of these ele- ments in the rock mass were calculated in different given volumes. With a voxel resolution of $5 \mathrm{~mm}^{3}$, to confirm the presence of a pore or a high-density mineral, only the elements of two voxels or more are considered, i.e., of a diameter in the range of $10 \mathrm{~mm}$.

The x-ray CT scans of the low-grade weathered bedrock ug13.06 sample show a low total poros-ity volume, organized according to planar shapes (Figure 6A). Pores are mostly located along crack planes. Within an analyzed cubic cell of $15.625 \mathrm{~mm}^{3}$, the identified pore volume is $0.0471 \mathrm{~mm}^{3}$, giving a porosity ratio of $0.30 \%$. Scans of the intermediately weathered ug13.18 sample show an increase in pore volume, located mainly along wider open cracks (Figure 6B). In a same-sized $15.625-\mathrm{mm}^{3}$ cell, the identified pore volume is $0.4713 \mathrm{~mm}^{3}$, and the po- rosity ratio is $3.02 \%$. The 3 -D cross sections show that the porosity increase between these two samples is controlled by the development and widening of cracks. Scans of the completely weathered ug13.39 sample highlight different pore geometry, consisting of both planar and vacuole-shaped voids. The planar voids cor respond to the crack porosity already identified in the less weathered samples, whereas the vacuole-shaped voids correspond to a newly formed matrix po- rosity, especially well developed in some minerals (Figure 6C). Within a larger analyzed rectangular cell of $104.64 \mathrm{~mm}^{3}$, the pore volume identified is $9.1555 \mathrm{~mm}^{3}$, giving a total porosity ratio of $8.75 \%$. The 3-D cross sections show that the porosity increase is mainly caused by the development of vacuole- shaped matrix porosity in some of the transformed minerals because of weathering. Crack density is slightly higher than that observed in the intermediately weathered ug13.18 sample, but secondary material infillings partially plug these structures. The estimated porosity given above was calculated in an average mass rock cell, without any distinction between the different mineral phases. However, the x-ray CT scanner allows specific areas to be targeted. Thus, the porosity volume of cells of approximately $1 \mathrm{~mm}^{3}$, composed of each of the different main minerals of this completely weath- ered sample, is computed directly: fissured quartz, plagioclase residues, kaolinite aggregates, and the weathering mixture (Figure 6D). The fissured quartz porosity (yellow) is a pure fracture porosity estimated at $6.00 \%$. Pores of the plagioclase residues (blue) have vacuole shape, consisting of an intramineral porosity estimated as $15.15 \%$. However, a larger volume of approximately $5 \mathrm{~mm}^{3}$ of such plagioclase residues has been investigated, considering planar structures like transmineral cracks partly filled by secondary material. The calculated porosity is $9.17 \%$ for this cell. The kaolinite aggregate porosity (orange) con- sists of intermineral interconnected pores and is esti- mated at $20.47 \%$. Finally, the weathering mixture porosity (green) is mostly vacuole-shaped, consisting of residual open spaces within secondary material coating, and is estimated at $6.31 \%$.

The highest density elements were also in- vestigated by x-ray CT scans. According to micro- scopic observations, these are interpreted as iron-rich oxides. These elements of the three ug13.06, ug13.18, and ug13.39 samples were computed in different sized cells of $15.625,56.423$, and $104.64 \mathrm{~mm}^{3}$, re- spectively (Figure 6E-G). The proportion of these highest density elements was estimated for the three samples, at $0.108 \%, 0.137 \%$, and $0.256 \%$ per unit volume. In the ug13.06 and ug13.18 samples, these elements with similar proportions generally have a nodular shape and are rarely located along crack planes, whereas in the ug13.39 samples, their proportion is increased, and several of them have a clear planar shape. These results tend to confirm the increase of iron-rich phases with weathering as secondary infilling material observed at the micro- scopic scale. 


\section{Mercury Intrusion Porosimetry Results}

Mercury intrusion porosimetry tests were carried out on two fragments per sample, to enhance the representativeness of pore distribution within the material. The intrusion curves are represented in Figure 7A, B, and the parameters measured are summarized in Table 4, showing the values of total porosity ( $\mathrm{f})$, skeletal $\left(\mathrm{d}_{\text {solid }}\right)$, and bulk $\left(\mathrm{d}_{\text {bulk }}\right)$ densities and median throat pore size (threshold diameter value when half of the mercury has filled up the total connected pore volume during the first intrusion). The results of MIP tests are correlated to SEM images of samples (Figure 8). It is also important to point out that the systematic sharp variation observed for most of the samples at a pore throat diameter of approximately $7 \mathrm{~mm}$ corresponds to an experimental artifact of the analytical device. However, this does not introduce significant errors into the overall sample data set (Giesche, 2006).

Lower-grade samples (facies I and II) show low connected porosity values, ranging in a narrow in- terval of approximately $2 \%$, with a minimum value of $0.46 \%$, except for the ug $13.06-2$ fragment that has a porosity of $3.22 \%$. The bulk and skeletal density

values of the samples are similar, 2.63 and $2.59 \mathrm{~g} \mathrm{~cm}^{-3}$ on average, respectively. The average median throat pore diameter is $0.16 \mathrm{~mm}$, ranging between 0.06 and $0.29 \mathrm{~mm}$. The intrusion curves of these fresh or slightly weathered samples are characterized by a bimodal distribution with a low slope for throat pore diameters greater than $1 \mathrm{~mm}$ and a steeper slope for smaller throat size (Figure 7A). A slope reduction or a plateau development is generally observed for di- ameter values less than $0.01 \mathrm{~mm}$, suggesting a quasisaturation of the pore networks. Thus, most of the pores of these samples belong to one pore set with diameters ranging from 0.01 to $0.5 \mathrm{~mm}$. A trend can be identified within this sample group. An increase of the total porosity among the samples comes gen- erally with a widening of the throat size range; that is, thresholds of the ug13.28 sample $(\mathrm{f}=1.43 \%)$ range between 0.01 and $0.1 \mathrm{~mm}$, whereas those of the ug13.06 sample ( $\mathrm{f}=2.03 \%$ ) range from 0.01 to $0.4 \mathrm{~mm}$. From SEM observations, these low total porosity values and the small throat distribution are attributed to a network mostly composed of micro- cracks and open grain boundaries (Figure 8A, B). Furthermore, a minor part of the pore volume can be located in accessory minerals, for instance, along bi- otite cleavages. As cracks are rare in these subfresh samples, the porosity volume consists of intracrystal- line and intercrystalline planar microcracks. The samples of this category differ in microcrack abun- dance, length, and aperture, but no strong variations in total porosity are observed.

Intermediately weathered samples (facies III) are characterized by a slight total porosity increase, with values ranging between $3.31 \%$ and $9.81 \%$ for the six fragments analyzed. The different parameters measured appear to be more variable than those of low weathered samples. Properties of ug14.50-2 stand out and are even more similar to some of the facies I and II sample characteristics (e.g., ug13.06-2). However, some trends appear with the weathering development, such as a bulk density decrease or a median pore throat size increase. The average skeletal density is $2.60 \mathrm{~g} \mathrm{~cm}^{-3}$, ranging between 2.52 and $2.64 \mathrm{~g} \mathrm{~cm}^{-3}$, whereas the average bulk density is $2.43 \mathrm{~g} \mathrm{~cm}^{-3}$, -ranging between 2.32 and $2.53 \mathrm{~g} \mathrm{~cm}-3$. The median throat pore is $0.40 \mathrm{~mm}$ in average, ranging between 0.16 and $0.69 \mathrm{~mm}$. The intrusion curves of the intermediately weathered samples are characterized by a trimodal distribution (Figure 7A). Toward the highest pressure values, intrusion is still effective, and no plateau is observed. Saturation of the porous network is not reached, which suggests the pres- ence of pores smaller than $5 \mathrm{~nm}$, probably related to the intergrain space of secondary clay minerals. This small-sized pore set represents a minor part of the porosity volume. The $0.01-0.5 \mathrm{~mm}$ pore set observed in the low weathered samples is also identified, with the steeper part of the intrusion curves ranging be- tween 0.05 and $0.5 \mathrm{~mm}$, and this represents about half of the total porosity volume. This significant porous volume is attributed to the development and opening of intracrystalline and intercrystalline micro- cracks (Figure 8C). The third part of the pore distribution corresponds to an intrusion measured for thresholds from 1 to $300 \mathrm{~mm}$. This larger pore set is attributed to the development of cracks and joints with the weather- ing brecciation effect (Figure 8D). Thus, planar discontinuities with either inframicrometric (mi- crocrack) or micrometric (crack, joint) scale ap- ertures constitute two different sized throat sets, with each representing about half of the total porosity volume.

The MIP tests of the completely weathered samples (facies V) were carried out on eight fragments characterized by high total porosities ranging between $27.22 \%$ and $39.62 \%$ with an average value of $32.39 \%$. Despite the variability in the parameters measured, an increase of total porosity volume and 
median pore throat size and a decrease of bulk density can be noticed. The average skeletal density is 2.54 $\mathrm{g} \mathrm{cm}^{-3}$, ranging between 2.45 and $2.60 \mathrm{~g} \mathrm{~cm}^{-3}$, whereas show a common dominant pore set with thresholds between diameters of 0.5 and $5 \mathrm{~mm}$. A secondary pore set with a larger threshold, greater than $5 \mathrm{~mm}$ in diameter, is also observed within these samples. These two pore sets are related both to preserved and unsealed joints or cracks and to the effect of strong chemical weathering. From the SEM observations, the larger pore set $(5-300 \mathrm{~mm})$ is attributed to preserved joints and to vacuoles developed by leaching and dissolution of some of the primary mineral phases (e.g., albite) (Figure 8E, F). The chemical alteration of these mineral phases comes with the development of secondary aggregated clay minerals (kaolinite), partly filling some of the vac- uoles and planar discontinuities. The dominant pore set $(0.5-5 \mathrm{~mm})$ is mainly attributed to vacuoles and to the intergrain porosity located between clay aggregates, which represent the major pore vol- ume in these samples (Figure 8G, H). Smaller pores $(<0.5 \mathrm{~mm})$ correspond to preserved intra- crystalline and intercrystalline microcracks in quartz or K-feldspar or smaller interclay aggregate spaces. This inframicrometric pore set is larger for the two ug13.38- 39 samples, where an intrusion peak is identified be- tween 0.01 and $0.05 \mathrm{~mm}$. These two samples are similar to ug13.34-35 samples in terms of clay content but have much more iron-rich hydroxides and amorphous gel, which may host this specific pore set (Figure 8E).

\section{Skeletal Density, Permeability, and P-Wave Propagation Velocity Measurement Results}

Skeletal density $\left(\mathrm{d}_{\text {solid }}\right)$ with helium pycnometer, P-wave propagation velocity $\left(\mathrm{V}_{\mathrm{p}}\right)$, and nitrogen permeability (k) measurements were carried out on the different weathered samples (Table 5).

The average skeletal density of all these samples is $2.632 \mathrm{~g} \mathrm{~cm}^{-3}$, with values ranging between 2.607 and $2.657 \mathrm{~g} \mathrm{~cm}-3$. No clear variations in relation to the different facies of the samples can be identified. Despite mineralogical transformations with weathering, the skeletal density is homogeneous in this weathering profile.

Both ug13.27 and ug13.28 samples are consid- ered as fresh (facies I) samples of the study, and they stand out from the other specimens by their $\mathrm{V}_{\mathrm{p}}$ and $\mathrm{k}$ properties. Their high P-wave propagation velocity values, 5144 and $5483 \mathrm{~m} \mathrm{~s}^{-1}$, and their low perme- ability values, $2.0 \cdot 10^{-4}$ and $3.7 \cdot 10^{-4} \mathrm{md}$, can be considered as reference values for fresh samples of crystalline basement. From the ug13.28 sample that shows the highest values, the P-wave propa- gation velocity decreases steadily with weathering to $933 \mathrm{~m} \mathrm{~s}^{-1}$ for the ug13.39 sample (facies V). The $V_{p}$ measurements of facies II samples are variable, whereas those of both intermediately and highly weathered samples appear to be stacked around specific values, 2500 and 1000 $\mathrm{m} \mathrm{s}^{-1}$, respectively. However, the measurement of ug14.50 sample (fa- cies III) suggests that this sample might be closer to facies II. Finally, gaps between the values highlight the different weathering grades of this sample panel. Weathering also changes the crystalline basement from an impermeable rock to a permeable one. However, value variation is not as steady as that of $V_{p}$ measurements. Some of the low weathered samples (facies I-II) are characterized by very low permeability of approximately $10^{-4} \mathrm{md}$. The higher $\mathrm{k}$ values of approximately $1 \mathrm{md}$ of both ug13.06 and ug13.07 samples (facies II) are similar to some of the measurements of samples with higher degree of

weathering and are not representative to the prop- erties of the low weathered rock matrix. Variable $\mathrm{k}$ values are measured in the intermediately to completely weathered samples, ranging between 1.6 and $939 \mathrm{md}$.

Relationships between Porosity and Bulk Density, P-Wave Propagation Velocity, and Permeability

The three following petrophysical properties were plotted against porosity: bulk density, permeability, and P-wave propagation velocity (Figure 9A, B). A clear linear relationship is identified between porosity (f) and bulk density ( $\left.d_{\text {bulk }}\right)$ of the samples with a good regression factor $\left(R^{2}=0.997\right)$ (Figure $\left.9 A\right)$, expressed as

$\mathrm{d}_{\text {bulk }}=2: 628-0: 028 \mathrm{f}$ 
The relationships between porosity and P-wave prop- agation velocity or permeability are more complex (Figure 9B). Both curves show the most significant variations in the low-porosity samples below $10 \%$. In contrast, after the value gap between $10 \%$ and $25 \%$, for high-porosity samples the P-wave propagation velocity and permeability properties appear to stabilize. The values obtained for these three different property measurements, especially for facies I to III samples, are in the range of other published data from core samples and borehole analysis or subsurface geophysics (Katsura et al., 2009; Olona et al., 2010; Mohd-Nordin and Mohamed, 2014). However, such data for more highly weathered facies appear to be scarce in the lit- erature. For instance, the sharp wave velocity and permeability variations from fresh to intermediately weathered samples are comparable to those described for granite rocks within fault zones or to variations observed in samples that have been experimentally strained (Nur and Simmons, 1969; Kowallis and Wang, 1983; Pros et al., 1998; Chaki et al., 2008; Va'zquez et al., 2010; Stane k et al., 2013). These variations are generally described as a result of a crack network modification (Walsh and Brace, 1984; Bernabe' , 1986). For higher weathering grades (i.e., facies V), the pet- rophysical property relationships are different because of a different tubular or vacuole-shaped dominant pore network (Gueguen and Dienes, 1989; Sarout, 2012).

Simple porosity-permeability relationships have been proposed in the literature with porosity as the main variable. However, the porosity factor is commonly not sufficient enough to properly describe the permeability changes, and other parameters have to be considered (e.g., Scheidegger, 1974; Walsh and Brace, 1984; Gueguen and Dienes, 1989; Gueguen and Palciauskas, 1992; Bernabe' et al., 2003; Tiab and Donaldson, 2004; Zinszner and Pellerin, 2007; Sarout, 2012). In a simple way permeability can be expressed as:

$\mathrm{k}=\mathrm{FL}^{2}$

where the permeability $\mathrm{k}$ is the product of a squared length scale $\mathrm{L}^{2}$ depending on the porous network and a dimensionless factor F (Bernabe' et al., 2010). One of the most commonly used forms of this equation is

Kozeny's hydraulic radius formula:

$\mathrm{k}={ }_{\mathrm{G}} \mathrm{R}_{\mathrm{h}}^{2}$

where $\mathrm{f}$ is the porosity, $\mathrm{G}$ is a dimensionless geometrical factor, and $\mathrm{R}_{\mathrm{h}}$ is the hydraulic radius (Scheidegger, 1974; Walsh and Brace, 1984). The $R_{h}$ value can be obtained from MIP tests because the hydraulic radius is equivalent to the percolation threshold if tubular shape geometry is assumed for the porous network (Brace et al., 1968; Okazaki et al., 2014). Thus, the hydraulic radius can be expressed as $R_{h}={ }^{R_{0}}$, where $R_{o}$ is the geometric pore radius.According to these equations and assumptions, the $G$ factor can be calculated from different pa- rameters $\left(\mathrm{k}, \mathrm{f}\right.$, and $\left.\mathrm{R}_{\mathrm{o}}\right)$ obtained from permeability and MIP measurements. This $\mathrm{G}$ factor can be considered as representative of the pore network complexity. From Kozeny's hydraulic radius equation with constant $f$ and $R_{0}$, the lower $k$ is, the higher $G$ is. Indeed, the $G$ factor is a complex parameter resulting from the conjugate effects of several geometrical parameters like tortuosity, connectivity, pore shape, and threshold variations, as well as the roughness of the pore surfaces or the number of voids available for fluid transfer. Therefore, we attempted to estimate the changes of pore geometry along the weathering profile, from $\mathrm{G}$ factor variations between different weathered samples.

From the different measurements presented above, the $\mathrm{G}$ factor of the samples is determined according to the equation

$\mathrm{fR}_{\mathrm{o}}{ }^{2 \mathrm{G}=} 4 \mathrm{k}$

and is plotted against the permeability in Figure 9C. Values obtained for the different samples of this study are presented in Table 5. Two distinct sample sets can be identified. The first group consists of the facies I, 
II, and III samples, showing a common evo- lution of the G factor over five orders of magnitude associated to the permeability variations over six or- ders of magnitude. The $G$ factor decreases with the weatheringrelated permeability increase related to the planar structure-dominated porosity development (joints, fractures, and microcracks) in the lower fresh and saprock parts of the profile. The development of larger structures in the facies III samples with weath- ering, relative to those of the facies I and II samples, increases the connectivity and reduces the tortuosity of the porous network. The second group consists of samples of the saprolite part of the profile (facies $V$ ), with evolution of the $G$ factor over three orders of magnitude, associated with permeability variations over two orders of magnitude. The $G$ factor values of these samples are higher than those of the lower parts of the weathering profile, with similar permeability values. This observation highlights a more complex porosity network, composed of a dominant vacuole-shaped pore set and a secondary planar-shaped pore set according to the MIP measurements and the SEM observations.

\section{DISCUSSION}

The multilayered weathering profile of crystalline basement rock consists of a composite system where each layer is characterized by specific properties (Wright, 1992). In this study, samples representative of fresh bedrock, the saprock unit, and the saprolite unit show significant differences in their mineralog-ical and petrophysical properties. The upper unit of the theoretical profile, the residual soil with lat- eritic concretions, was not found in the study area and so was not analyzed.

Through mineralogical investigations, major changes are revealed with weathering, especially in clay mineral composition and content, with a low content $(<1 \%)$ of smectite-dominated assemblies in the lower part of the weathering profile and a high content $(>5 \%)$ of kaolinite-dominated assemblies in the saprolite-like samples (facies V). These trans- formations come with petrophysical variations and are characterized by general trends with weathering such as porosity and permeability increases and bulk density and P-wave propagation velocity decreases. Despite petrological transformations, no clear solid phase density variation is observed. According to our observations, especially of the major mineralogical components, the main transformation is kaolin- ite development along with albite disappearance, whereas quartz and microcline are mostly pre- served. Because kaolinite and albite densities are similar, 2.599 and $2.610 \mathrm{~g} \mathrm{~cm}^{-3}$, respectively (Smyth and McCormick, 1995), no significant solid-phase density variations are induced, nor with the devel- opment of minor accessory minerals like iron oxides or hydroxides. Therefore, the bulk density variations measured for the different samples along the theo- retical weathering profile can be attributed to porosity variations of the samples.

The saprolite layer of crystalline basement rocks is considered as a clay-rich porous medium (Wright, 1992). As a consequence of the clay enrichment at the top of the profile with weathering, many reports in the literature describe highly variable hydraulic properties in the saprolite layer, with a general de- crease toward the top of this layer (e.g., Acworth, 1987; Chilton and Foster, 1995; Taylor and Howard, 2000; Dewandel et al., 2006) (Figure 1C). This clay plug effect can be reinforced by a compaction effect resulting from the mechanical stiffness decrease by dissolution of some of the main mineral phases (Turner et al., 2003; Angerer et al., 2011a). In the present study, the completely weathered samples representative of the saprolite unit retained a high permeability, no difference from those of the lower saprock unit (Figure 9B). Despite chemical alter- ation and clay development in the saprolite layer, we suggest that these samples show an incomplete secondary clay material filling and plugging of pore spaces. The eastern Lake Albert area underwent a geomorphic stripping phase that began when Miocene rifting modified the base level and is still active (Taylor and Howard, 1998, 2000). This long-term stripping regime induced hydrodynamic drainage, which could prevent complete plugging of the clay-rich, highly weathered parts of the base- ment. The rock cohesion of these felsic granulitic and orthogneiss rocks is partly preserved despite the leaching processes, as a skeletal texture re- mains, consisting of joined quartz and microcline that are somewhat preserved from weathering. High-permeability pore spaces within dissolution structures or fractures remain open and connected, without total clay filling or rock compaction. This observation is confirmed by MIP tests and SEM images, with significant pore volume of diame- ter greater than $10 \mathrm{~mm}$ (Figures 7B, 8E, F). Thus, saprolite permeability is similar to that of saprock- like samples (facies III), which are generally de- scribed as the layer of the weathering profile with the highest transfer properties (Wright, 1992; Chilton and Foster, 1995). 
However, except for skeletal density and per- meability properties, the other observations and measurements undertaken show significant differ- ences between the lower fresh and saprock parts and the saprolite part of the weathered basement. Most of the following data obtained by characterizing these different weathered parts are summarized in Figure 10. Figure 10 highlights the strong property contrast between the saprock and saprolite layers. Figure 10 shows also the different petrophysical evolution of this profile and of a profile generally described in the literature (Acworth, 1987).

Similar permeability values and variations in porosity volume and dominant pore threshold ge- ometry between facies III and V suggest significant differences in the connectivity of the porous net- work (Gueguen and Dienes, 1989; Gueguen and Palciauskas, 1992; Sarout, 2012). Saprock-like sam- ples with smaller pore volume and pore size than those of saprolite-like samples show higher connectivity. This observation can be correlated to the dominant planar shape of the facies III voids, whereas the facies $\mathrm{V}$ vacuole-shaped pores are less favorable for the development of high connectivity. Concerning macroscopic criteria, no facies IV samples were identified in the field. This absence, associated with the sharp variation of some petrophysical properties between facies III and V samples, such as the total porosity or the P-wave propagation velocity, suggests a sharp

transition between the saprock and saprolite facies. In this case study, facies IV might not exist, especially because literature reports commonly describe a sharp weathering front bounding the saprolite layer to the bedrock in warm and humid climates (e.g., Braun et al., 2012; Hewawasam et al., 2013). This petrological limit separates two domains with contrasting petrophysical properties. From fresh (facies I) to mod- erate (facies III) samples, a subcontinuous evolution of petrophysical properties is seen. Considering the porosity network properties from the MIP analyses, samples ug13.06-2 and ug14.50-2 show similar characteristics, although they correspond to facies II and III, respectively, according to macroscopic criteria. These two samples can be considered as tran- sition samples between these two facies. From various observations, the qualitative density increase of dif- ferent sized planar structures (joints, fractures, and microcracks) with the degree of weathering can ex- plain the subcontinuous evolution of petrophysical properties in the lower part of the profile. Thus, the fresh and saprock units (facies I-III) of the weathering profile are characterized by a planar structure- controlled porosity network, with total pore vol- ume increasing up to $8 \%-10 \%$, developed by physical weathering processes, e.g., rock cohesion loss by high differential stress relaxation near the ground surface (Holzhausen, 1989), vertical or horizontal unloading (Wang and Simmons, 1978; Kowallis and Wang, 1983; Vollbrecht et al., 1991; Bahat et al., 1999), tectonic stress relief (Vollbrecht et al., 1994; Vidal Romaní; and Twidale, 1999), temperature variations (Wang et al., 1989; Voll- brecht et al., 1991; Ge'raud, 1994), or volume ex- pansion during chemical alteration of primary minerals (Ferry, 1979; Bisdom et al., 1982; Kami- neni et al., 1993). The high permeability and con- nectivity properties related to the significant open cracks, fractures, and joints system and the low clay content of the facies III samples confirm that the saprock-like layers represent high-transfer zones for fluid circulation in the weathering profile. The strong mineralogical and petrophysical differences between the completely weathered samples (facies V) and those of the lower parts of the profile are caused by a change in the main weathering mech- anism. Chemical weathering with leaching and dis- solution of primary mineral phases produced matrix porosity, mainly composed of vacuole structures, with a total pore volume of up to $40 \%$. The high porosity and permeability values confirm that the saprolite-like layers represent high storage zones for fluid circulation in the weathering profile. These clay-rich layers with high reservoir properties may be preserved from complete plugging by long-term hydrodynamic drainage.

The typical trap type described in the literature from the architecture of several hydrocarbon basement

reservoirs is a basement high formed by a horst block, a buried hill, or pop-up structure, covered and juxtaposed by a sedimentary cover that acts as both seal and source rock (Gutmanis, 2009; Murray and Montgomery, 2014). In such basement reservoirs, the primary porosity is negligible, and fluids are constrained to secondary porous networks, mainly in fault and fracture systems and within secondary rock matrix porosity located along hydrothermally altered fault zones and top weathered formations (Petford and McCaffrey, 2003).

Weathered zones of basement, commonly con- fined to the upper reaches of the paleobasement surface, are not systematically regarded as potential zones of interest, although they can sometimes pro- vide areas of increased fracture and matrix porosity (up to $40 \%$ in this study) and are significant factors in 
fluid transfers when they are buried below sedi- mentary basins. Several ore research studies showed that the basement-sedimentary cover unconformity can play as a major circulation zone for fluids, espe- cially when the top of the basement formations are weathered (e.g., Pique' et al., 2008; Boiron et al., 2010; Cathelineau et al., 2012). In the case of a basin with hydrocarbon potential, such an interface can act as a favorable migration pathway. Regarding the re- sults of this study, as well as some examples from the literature of higher hydrocarbon production located in the upper section of basement reservoirs (e.g., Augila field, Lybia [P’an, 1982], and Zeit Bay field, Egypt [Salah and Alsharhan, 1998; Younes et al., 1998]), the paleoweathering profile also represents a significant storage zone, if it is preserved over a thickness of several tens of meters (several tens of feet). Considering the pervasive fault and fracture networks, which can affect basement rocks and deeply drive weathering haloes along open brittle structures, some authors suggest that hydrocarbons can migrate up to $300 \mathrm{~m}(\sim 1000 \mathrm{ft})$ deep below the cover- basement interface (e.g., Aguilera, 1995; Cuong and Warren, 2009). Reservoir properties of such weath- ered formations appear to be interesting for oil recovery. In addition to the high porosity and connectivity relative to fresh basement formations, the signifi- cant enlargement of pore throat size up to three orders of magnitude highlighted in this study im- plies a significant decrease of capillary pressure needed to recover hydrocarbons.

Seismic maps of fault attributes of hydrocarbon field examples (e.g., Yufutsu field, Japan [Tamagawa et al., 2012]; Cuu Long basin, Vietnam [Ngoc et al., 2014]; and Lancaster field, United Kingdom [Slightam, 2014]) show that these basement highs are composed of interlocking parallelogram-shaped structural blocks of different sizes, bounded by fault zones. The faults act as major conduits for fluid flow, whereas reservoir storage is located in the rock mass within the structural blocks. The reservoir matrix is

composed of tectonic and primary fractures but could also be composed of weathering-related secondary porosity. To describe this "self-similar" fault-bounded block geometry broadly recognized for hydrocarbon basement reservoirs, Le Garzic et al. (2011) proposed a basement fractured res- ervoir model based on a surface analog study. This study consisted of the multiscale structural map- ping of the crystalline Al-Mukala basement (Yemen), of approximately $100 \mathrm{~km}$ ( $\sim 62 \mathrm{mi})$ south to the well- known basement reservoir of Kharir (e.g., De Ur- reiztieta et al., 2007). According to this model, the fault zones bounding the structural blocks of the basement reservoirs have hierarchical organization of geometrical parameters such as length or spacing, and different dimensions orders can be defined. From this structural organization and the petrophysical results of this study, an estimation of the reservoir capacity of a third-order basement fault-bounded block of approximately $800 \mathrm{~m}(\sim 2900 \mathrm{ft})$ wide is proposed. This estimation is reasonable because the dimensions of such third- order structural blocks correspond approximately to those of the blocks targeted by one or several wells in the reservoirs cited above (e.g., Tamagawa et al., 2012; Ngoc et al., 2014). Considering a preserved weathering paleoprofile with a top saprolite layer of approximately $10 \mathrm{~m}(\sim 33 \mathrm{ft})$ thick with $25 \%$ porosity and an underlying saprock layer of approximately $20 \mathrm{~m}(\sim 66 \mathrm{ft})$ thick with $5 \%$ porosity, the maximum storage capacity of such weathered formations could reach 2.24 million $\mathrm{m}^{3}$ per basement block, i.e., 3.5 million $\mathrm{m}^{3}$ per $\mathrm{km}^{2}$ of reservoir. Weathering can, therefore, produce significant porosity volume at the reservoir scale, in addition to the potential underlying porosity related to the tectonic and primary fractures of the crystalline basement.

With regard to this study, several proxies for cutting analyses and well logging can be defined for the recognition of such targets. A subcontinuous evolution over several tens of meters (several tens of feet) of bulk density and P-wave propagation veloc- ity, from $2.7-2.6$ to $2.3-2.2 \mathrm{~g} \mathrm{~cm}^{-3}$ and approximately 5000 to $2500 \mathrm{~m} \mathrm{~s}^{-1}$ respectively, could highlight fractured basement rocks of the saprock horizon. Furthermore, a major increase of kaolinite content, present as more than $5 \%$ in bulk rock composition, associated to sharp bulk density and P-wave decrease propagation velocity decreases (below $2.0 \mathrm{~g} \mathrm{~cm}^{-3}$ and $1000 \mathrm{~m} \mathrm{~s}^{-1}$, respectively) could highlight the in- tensively weathered basement layers of the saprolite horizon. Variations with weathering of other petro- physical parameters like resistivity, thermal con- ductivity, nuclear magnetic resonance, or magnetic susceptibility should be investigated to enhance this proxy panel.

\section{CONCLUSION}

The multimethod mineralogical and petrophysical characterization of a composite weathering profile of the western Uganda Archaean crystalline base- ment reveals two distinct domains separated by a sharp 
property transition. For instance, $\mathrm{x}$-ray CT or mercury porosimetry highlight the pore network geometry difference between the lower (i.e., fresh and saprock units) and the upper (i.e., saprolite unit) parts of the profile, developed by dominant physical or chemical weathering mechanisms, respectively.

The lower part of the profile is characterized by a low-clay content planar structure-controlled po- rosity network (i.e., joints, fractures, and micro- cracks). The pore network of these layers shows high connectivity, with total pore volume of up to $8 \%-10 \%$ and permeability of up to $500 \mathrm{md}$, developed by different physical weathering mechanisms such as rock unloading or temperature variations. The upper part of the profile is characterized by a kaolinite-dominated high-clay content matrix poros- ity network with dominant vacuole-shaped pore structures developed by chemical weathering with leaching and dissolution of the primary mineral phases. The total pore volume of these layers reaches high values of approximately $30 \%$ and permeability of up to $1 \mathrm{~d}$. Both lower and upper parts of the weathering profile show interesting hydraulic properties for basement reservoirs, representing a potential high transfer zone and high storage zone, respectively, for fluid circulations. Variations of the pore network complexity (e.g., conjugate effects of tortuosity, connectivity, roughness, and pore shape variations) of both lower and upper parts are highlighted using a geometrical factor based from the literature about the description of porosity-permeability relation- ships and calculated from petrophysical data of this study.

Finally, this surface analog study described the mineralogical and petrophysical properties of the composite reservoir that can be developed in hot and humid climates by weathering in crystalline basement rocks. Long-term hydrodynamic drainage of the basement during weathering can prevent the second- ary weathering-related porosity from complete clay plugging. The remaining skeletal texture, consisting of joined nonaltered phases (quartz and microcline), maintains the rock cohesion and highpermeability pore spaces against rock compaction processes. After burial in hydrocarbon-rich sedimentary basins, the weathered basement paleoformations developed over a large area can significantly increase the potential of hydrocarbon basement reservoirs. Exploration of these unconventional reservoirs should therefore favor po- tential fields with top weathered formations. Finally, this study also corroborates the recommendation from Aguilera (1995, p. 60) made for conventional basin hydrocarbon exploration, suggesting to drill system- atically into basement "at least $300 \mathrm{~m}$ [...], specially if a source rock rests on top of the basement."

\section{REFERENCES CITED}

Aanyu, K., and D. Koehn, 2011, Influence of pre-existing fabrics on fault kinematics and rift geometry of interacting segments: Analogue models based on the Albertine Rift (Uganda), Western Branch-East African Rift System: Journal of African Earth Sciences, v. 59, no. 2-3, p. 168-184, doi:10.1016/j.jafrearsci.2010.10.003.

Abeinomugisha, D., and R. Kasande, 2013, Tectonic control on hydrocarbon accumulation in the intracontinental Albertine Graben of the East African Rift system, in D. Gao, ed., Tectonics and sedimentation: Implications for petroleum systems: AAPG Memoir 100, p. 209-228, doi:10.1306/13351554M1003539.

Acworth, R. I., 1987, The development of crystalline base- ment aquifers in a tropical environment: Quarterly Journal of Engineering Geology, v. 20, no. 4, p. 265-272, doi:10.1144/GSL.QJEG.1987.020.04.02.

Aguilera, R., 1995, Naturally fractured reservoirs: Tulsa, Oklahoma, PennWell Books, 521 p.

Ahn, J. H., and D. R. Peacor, 1987, Kaolinitization of biotite; TEM data and implications for an alteration mechanism: American Mineralogist, v. 72, no. 3-4, p. 353-356.

Alai, R., A. A. Aqrawi, A. B. Mohamed, and M. T. A. Taha, 2014, Fracture characterization in basement reservoirs through seismic attributes: First Break, v. 32, no. 10, p. 83-92.

Angerer, T., R. O. Greiling, and D. Avigad, 2011a, Fabric development in a weathering profile at a basement-cover interface, the sub-Cambrian peneplain, Israel: Implications for decollement tectonics: Journal of Structural Geology,

v. 33, no. 5, p. 819-832, doi:10.1016/j.jsg.2011.03.010. Angerer, E., P. Neff, I. Abbasi, and G. Ghiglione, 2011b, Integrated reservoir characterization of a fractured base- ment reservoir: Leading Edge, v. 30, no. 12, p. 1408-1413, 
rocks: Geophysical Journal of the Royal Astronomical Society, v. 76, no. 1, p. 113-119, doi:10.1111/j.1365246X.1984.tb05026.x.

Babus`ka, V., and Z. Pros, 1984, Velocity anisotropy in granodioriteandquartziteduetothedistributionof microcracks: Geophysical Journal of the Royal Astro- nomical Society, v. 76, no. 1, p. 121-127, doi:10.1111/j.1365246X.1984.tb05027.x.

Bahat, D., K. Grossenbacher, and K. Karasaki, 1999, Mecha- nism of exfoliation joint formation in granitic rocks, Yosemite National Park: Journal of Structural Geology, v. 21, no. 1, p. 85-96, doi:10.1016/S0191-8141(98)00069-8.

Batte, A. G., A. Muwanga, P. W. Sigrist, and M. Owor, 2008, Vertical electrical sounding as an exploration technique to improve on the certainty of groundwater yield in the fractured crystalline basement aquifers of eastern Uganda: Hydrogeology Journal, v. 16, no. 8, p. 1683-1693, doi: 10.1007/s10040-008-0348-4.

Bernabe',Y.,1986,Theeffectivepressurelawforpermeability in Chelmsford granite and Barre granite: International Journal of Rock Mechanics and Mining Sciences \& Geo- mechanics Abstracts, v. 23, no. 3, p. 267-275, doi: 10.1016/0148-9062(86)90972-1.

Bernabe', Y., C. Bruderer-Weng, and A. Maineult, 2003, Permeability fluctuations in heterogeneous networks with different dimensionality and topology: Journal of Geophysical Research, v. 108, no. B7, 2351.

Bernabe', Y., M. Li, and A. Maineult, 2010, Permeability and pore connectivity: A new model based on network simulations: Journal of Geophysical Research, v. 115, B10203, doi:10.1029/2010JB007444.

Birch, A. F., 1960, The velocity of compressional waves in rocks to 10 kilobars-Part 1: Journal of Geophysical Research, v. 65, no. 4, p. 1083-1102, doi:10.1029/JZ065i004p01083.

Bisdom, E. B. A., G. Stoops, J. Delvigne, P. Curmi, and H.J.Altemüller,1982,Micromorphologyofweathering biotite and its secondary products: Pédologie (Gent), v.32,no.2,p.225-252.

Bishop, W. W., and A. F. Trendall, 1966, Erosion-surfaces, tectonics and volcanic activity in Uganda: Quarterly Journal of the Geological Society of London, v. 122, no. 1-4, p. 385-420, doi:10.1144/gsjgs.122.1.0385.

Bjorlykke, K., 1975, Mineralogical and chemical changes during weathering of acid and basic rocks in Uganda: Norsk Geologisk Tidsskrift., v. 55, no. 1, p. 81-89.

Boiron, M.-C., M. Cathelineau, and A. Richard, 2010, Fluid flows and metal deposition near basement /cover unconformity: Lessons and analogies from Pb-Zn-F- Ba systems for the understanding of Proterozoic U deposits: Geofluids, v. 10, p. 270-292.

Brace, W. F., J. B. Walsh, and W. T. Frangos, 1968, Perme- ability of granite under high pressure: Journal of

Geophysical Research, v. 73, no. 6, p. 2225-2236, doi:

10.1029/JB073i006p02225.

Braun, J.-J., J.-C. Marechal, J. Riotte, J.-L. Boeglin, J.-P. B. Bedimo,

J. R. N. Ngoupayou, B. Nyeck, et al., 2012, Elemental weathering fluxes and saprolite production rate in a Central African lateritic terrain (Nsimi, South Cameroon): Geo- chimica et Cosmochimica Acta, v. 99, p. 243-270, doi: 10.1016/j.gca.2012.09.024.

Bronger, A., 2007, Time dependence of the rate and direction of mineral weathering and clay mineral formation with special consideration of kaolinites: Revista Mexicana de CienciasGeolo'gicas,v.24,no.3,p.510-523.

Cathelineau, M., M.-C. Boiron, S. Fourcade, G. Ruffet, N. Clauer, O. Belcourt, Y. Coulibaly, D. A. Banks, and F. Guillocheau, 2012, A major Late Jurassic fluid event at the basin/basement unconformity in western France: ${ }^{40} \mathrm{Ar} /{ }^{39} \mathrm{Ar}$ and $\mathrm{K}-\mathrm{Ar}$ dating, fluid chemistry, and related geodynamic context: Chemical Geology, v. 322-323, p. 99-120, doi:10.1016/j.chemgeo.2012.06.008. 
Chaki, S., M. Takarli, and W. P. Agbodjan, 2008, Influence of thermal damage on physical properties of a granite rock: Porosity, permeability and ultrasonic wave evolutions: Construction \& Building Materials, v. 22, p. 1456-1461, doi:10.1016/j.conbuildmat.2007.04.002.

Chilton, P. J., and S. S. D. Foster, 1995, Hydrogeological characterisationandwater-supplypotentialofbasement aquifers in tropical Africa: Hydrogeology Journal, v. 3, no. 1, p. 36-49, doi:10.1007/s100400050061.

Chilton, P. J., and A. K. Smith-Carington, 1984, Characteristics of the weathered basement aquifer in Malawi in relation to rural water supplies: IAHS-AISH Publication, v. 144, p. 57-72.

Chorowicz, J., 2005, The East African rift system: Journal of African Earth Sciences, v. 43, no. 1-3, p. 379-410, doi: 10.1016/j.jafrearsci.2005.07.019.

Cuong, T. X., and J. K. Warren, 2009, Bach Ho Field, a fractured granitic basement reservoir, Cuu Long Basin, offshore SE Vietnam, a "buried hill" play: Journal of Petroleum Geology, v. 32, no. 2, p. 129-156, doi: 10.1111/j.17475457.2009.00440.x.

Dearman, W. R., 1995, Description and classification of weathered rocks for engineering purposes: The back- ground to the BS5930:1981 proposals: Quarterly Journal ofEngineeringGeologyandHydrogeology,v.28,no.3, p. 267-276, doi:10.1144/GSL.QJEGH.1995.028.P3.05.

Debschütz,W.,U.S.Kruckel,andJ.R.Schopper,1989, Effects of geostatic stress and pore pressure on the Klinkenberg permeability factor and other fluid flow parameters: ISRM International Symposium, Pau, France, August 30September 2, 1989, p. 179-185.

Delvigne, J. E., 1998, Atlas of micromorphology of mineral alteration and weathering: Que'bec City, Que'bec, Can- ada, Mineralogical Association of Canada, 509 p.

De Urreiztieta, M., X. Troussaut, A. Baradi, G. Nagaraj, P. Tresse, J.-P. Meunier, J. Paillat, and J. Kloos, 2007, Formation testing strategy based on quick look data evaluation from a fractured basement reservoir: A case study from Kharir Field, Yemen: GeoArabia, v. 13, no. 3, p. 209-210.

Dewandel, B., P. Lachassagne, R. Wyns, J. C. Mare'chal, and N. S. Krishnamurthy, 2006, A generalized 3-D geological and hydrogeological conceptual model of granite aquifers controlled by single or multiphase weathering: Journal of Hydrology, v. 330, no. 1-2, p. 260-284, doi:10.1016/j .jhydrol.2006.03.026.

Deyassa, G., S. Kebede, T. Ayenew, and T. Kidane, 2014, Crystalline basement aquifers of Ethiopia: Their genesis, classification and aquifer properties: Journal of African Earth Sciences, v. 100, p. 191-202, doi:10.1016/j .jafrearsci.2014.06.002.

Dou, L., J. Wang, D. Cheng, X. Ran, E. N. T. Rubondo, R. Kasande, A. Byakagaba, and F. Mugisha, 2010, Geo- logical conditions and petroleum exploration potential of the Albertine Graben of Uganda: Acta Geologica Sinica, v. 78, no. 4, p. 1002-1010.

Doval, M., R. Mart'ın-Garćıa, A. La Iglesia, and A. M. Alonso- Zarza, 2012, Clay minerals associations in palaeoweathering profilesfromcentralSpain:Genesisandimplications: Clay Minerals, v. 47, no. 1, p. 117-129, doi:10.1180/ claymin.2012.047.1.117.

Dubois, C., Y. Quinif, J.-M. Baele, F. Dagrain, J. Deceuster, and O. Kaufmann, 2014, The evolution of the miner- alogical and petrophysical properties of a weathered limestone in southern Belgium: Geologica Belgica, v. 17, no. 1, p. 1-8.

Ebinger, C. J., 1989, Tectonic development of the western branch of the East African rift system: Geological Society of America Bulletin, v. 101, no. 7, p. 885-903, doi:10.1130 /0016-7606(1989)101<0885:TDOTWB>2.3.C0;2.

Ehlen, J., 2002, Some effects of weathering on joints in granitic rocks: Catena, v. 49, no. 1-2, p. 91-109, doi:10.1016 /S0341-8162(02)00019-X.

Ferry, J. M., 1979, Reaction mechanisms, physical conditions, and mass transfer during hydrothermal alteration of mica and feldspar in granitic rocks from south-central Maine, USA: Contributions to Mineralogy and Petrology, v. 68, no. 2, p. 125-139, doi:10.1007/BF00371895. 
Gaviglio, P., 1989, Longitudinal waves propagation in a lime- stone; the relationship between velocity and density: Rock Mechanics and Rock Engineering, v. 22, no. 4, p. 299-306, doi:10.1007/BF01262285.

Ge'raud, Y., 1994, Variations of connected porosity and in- ferred permeability in a thermally cracked granite: Geophysical Research Letters, v. 21, no. 11, p. 979-982, doi:10.1029/94GL00642.

Ge'raud, Y., F. Mazerolle, and S. Raynaud, 1993, Essai de quantification de la porosite d'un granite altere; utilisation du scanner medical (tomodensiometre X): Bulletin de la Socie'te'Ge'ologiquedeFrance,v.164,no.2,p.243-253.

Giesche, H., 2006, Mercury porosimetry: A general overview: Particle \& Particle Systems Characterization, v. 23, no. 1, 9 p., doi:10.1002/ppsc.200601009.

Gueguen, Y., and J. Dienes, 1989, Transport properties of rocks from statistics and percolation: Mathematical Geology, v. 21, no. 1, p. 1-13, doi:10.1007/BF00897237.

Gueguen, Y., and V. Palciauskas, 1992, Introduction a`la physique des roches: Paris, Hermann, 299 p.

Gutmanis, J. C., 2009, Basement reservoirs - A review of their geological and production characteristics: International Petroleum Technology Conference, Doha, Qatar,

December 7-9, 2009, IPTC-13156-MS, 7 p., doi:

10.2523/IPTC-13156-MS.

Gutmanis, J. C., T. Batchelor, S. Doe, and E. Pascual-Cebrian,

2015, Hydrocarbon production from fractured basement formations. accessed August 20, 2015, http://docs.wixstatic .com/ugd/309073_46b5fc2585a84fdf91bfb679047f7470.pdf.

Hepworth, J. V., and R. Macdonald, 1966, Orogenic belts of the northern Uganda basement: Nature, v. 210, no. 5037, p. 726-727, doi:10.1038/210726a0.

Hewawasam, T., F. von Blanckenburg, J. Bouchez, J. L. Dixon, J. A. Schuessler, and R. Maekeler, 2013, Slow advance of the weathering front during deep, supply- limited saprolite formation in the tropical Highlands of Sri Lanka: Geochimica et Cosmochimica Acta, v. 118, p. 202-230, doi:10.1016/j.gca.2013.05.006.

Holtzapffel, T., 1985, Les mineraux argileux; pre'paration, analysediffractome'triqueetde'termination:Lille,France, Socie'te' ge'ologique du Nord, v. 12, 136 p.

Holzhausen, G. R., 1989, Origin of sheet structure, 1. Morphology and boundary conditions: Engineering Geology, v. 27, no. 1-4, p. 225-278, doi:10.1016/0013-7952(89)90035-5.

Hower, J., 1981, Shale diagenesis: Short Course Handbook, v. 7, p. 60-80.

Jamtveit, B., M. Kobchenko, H. Austrheim, A. Malthe- Sørenssen, A. Røyne, and H. Svensen, 2011, Porosity evolution and crystallization-driven fragmentation during weathering of andesite: Journal of Geophysical Research, v. 116, B12204, doi:10.1029/2011JB008649.

Kamineni, D. C., R. Kerrich, and A. Brown, 1993, Effects of differential reactivity of minerals on the development of brittle to semi-brittle structures in granitic rocks: Textural and oxygen isotope evidence: Chemical Geology, v. 105, no. 1-3, p. 215-232, doi:10.1016/0009-2541(93) 90127-5.

Karp, T., C. A. Scholz, and M. M. McGlue, 2012, Structure and stratigraphy of the Lake Albert Rift, East Africa; observations from seismic reflection and gravity data, in O. W. Baganz, Y. Bartov, K. Bohacs, and D. Nummedal, eds., Lacustrine sandstone reservoirs and hydrocarbon systems: AAPG Memoir 95, p. 299-318.

Katsura, S., K. Kosugi, T. Mizutani, and T. Mizuyama, 2009, Hydraulic properties of variously weathered granitic bedrock in headwater catchments: Vadose Zone Journal, v. 8, no. 3, p. 557-573, doi:10.2136/vzj2008.0142. 
Katumwehe, A. B., M. G. Abdelsalam, and E. A. Atekwana, 2015, The role of pre-existing Precambrian structures in rift evolution: The Albertine and Rhino grabens, Uganda: Tectonophysics, v. 646, p. 117-129, doi:10.1016/j .tecto.2015.01.022.

King, B. C., M. J. Le Bas, and D. S. Sutherland, 1972, The history of the alkaline volcanoes and intrusive complexes of eastern Uganda and western Kenya: Journal of the Geological Society, v. 128, no. 2, p. 173-205, doi: 10.1144/gsjgs.128.2.0173.

Klinkenberg, L. J., 1941, The permeability of porous media to liquids and gases, in Drilling and production practice: New York, American Petroleum Institute, p. 41-200.

Kowallis, B. J., and H. F. Wang, 1983, Microcrack study of granitic cores from Illinois deep borehole UPH 3: Journal of Geophysical Research, v. 88, no. B9, p. 7373-7380,

doi:10.1029/JB088iB09p07373.

Lachassagne, P., R. Wyns, and B. Dewandel, 2011, The

fracture permeability of Hard Rock Aquifers is due neither to tectonics, nor to unloading, but to weathering processes: Terra Nova, v. 23, no. 3, p. 145-161, doi: 10.1111/j.1365-3121.2011.00998.x.

Landes, K. K., J. J. Amoruso, L. J. Charlesworth Jr., F. Heany, and P.-J. Lesperance, 1960, Petroleum resources in basement rocks: AAPG Bulletin, v. 44, no. 10, p. 1682-1691.

Le Garzic, E., T. de L'Hamaide, M. Diraison, Y. Ge' raud, J. Sausse, M. de Urreiztieta, B. Hauville, and J.-M. Champanhet, 2011, Scaling and geometric properties of extensional fracture systems in the proterozoic basement of Yemen. Tectonic interpretation and fluid flow implications: Journal of Structural Geology, v. 33, no. 4, p. 519-536, doi:10.1016/j .jsg.2011.01.012.

Leggo, P. J., 1974, A geochronological study of the basement complex of Uganda: Journal of the Geological Society, v. 130, no. 3, p. 263-277, doi:10.1144/gsjgs.130.3.0263.

Link, K., D. Koehn, M. G. Barth, J. V. Tiberindwa, E. Barifaijo, K. Aanyu, and S. F. Foley, 2010, Continuous cratonic crust between the Congo and Tanzania blocks in western Uganda: International Journal of Earth Sciences, v. 99, no. 7, p. 1559-1573, doi:10.1007/s00531-010-0548-8.

Luthi, S. M., 2005, Fractured reservoir analysis using modern geophysical well techniques; application to basement reservoirs in Vietnam, in P. K. Harvey, T. S. Brewer, P. A. Pezard, and V. A. Petrov, eds., Petrophysical properties of crystalline rocks: Geological Society, Lon- don, Special Publications 2005, v. 240, p. 95-106, doi:

10.1144/GSL.SP.2005.240.01.08.

McFarlane, M. J., 1983, A low level laterite profile from Uganda and its relevance to the question of parent ma- terial influence on the chemical composition of laterites, in R. C. L. Wilson, ed., Residual deposits: Surface related weathering processes: Geological Society, London, Special Publications 1983, v. 11, p. 69-76, doi:10.1144 /GSL.SP.1983.011.01.09.

Mellini, M., F. Nieto, F. Alvarez, and M. T. Gomez-Pugnaire, 1991, Mica-chlorite intermixing and altered chlorite from the Nevado-Filabride micaschists, southern Spain: Eu- ropean Journal of Mineralogy, v. 3, no. 1, p. 27-38, doi: $10.1127 /$ ejm $/ 3 / 1 / 0027$.

Miguel, A. F., and A. Serrenho, 2007, On the experimental evaluation of permeability in porous media using a gas flow method: Journal of Physics D: Applied Physics, v. 40, no. 21, p. 6824-6828.

Mohd-Nordin, M. M., and Z. Mohamed, 2014, Empirical correlation of P-wave velocity to the density of weathered granite: InCIEC 2013: Proceedings of the International Civil and Infrastructure Engineering Conference, v. 2013, p. 489-499.

Murray, A., and D. W. Montgomery, 2014, Characterization of highly fractured basement, Say'un Masila Basin, Yemen, in G. H. Spence, J. Redfern, R. Aguilera, T. G. Bevan, J. W. Cosgrove, G. D. Couples, and J.-M. Daniel, eds., Advances in the study of fractured reservoirs: Geological

Society, London, Special Publications 2014, v. 374, no. 1, 
p. 289-310, doi:10.1144/SP374.1.

Ngoc, N. H., S. B. Aziz, and N. A. Duc, 2014, The application

of seismic attributes for reservoir characterization in Pre- Tertiary fractured basement, Vietnam-Malaysia offshore: Interpretation, v. 2, no. 1, p. SA57-SA66, doi:10.1190 /INT-2013-0081.1.

Nieto, F., N. Velilla, D. R. Peacor, and M. Ortega Huertas, 1994, Regional retrograde alteration of sub-greenschist facies chlorite to smectite: Contributions to Mineralogy and Petrology, v. 115, no. 3, p. 243-252, doi:10.1007 /BF00310765.

Nur, A., and G. Simmons, 1969, The effect of saturation on velocity in low porosity rocks: Earth and Planetary Sci- ence Letters, v. 7, no. 2, p. 183-193, doi:10.1016/0012-821X(69)90035-1.

Nyakairu, G. W. A., H. Kurzweil, and C. Koeberl, 2002, Mineralogical, geochemical, and sedimentological characteristics of clay deposits from central Uganda and their applications: Journal of African Earth Sciences, v. 35, no. 1, p. 123-134, doi:10.1016/S0899-5362(01)00077-X.

Nyende, J., G. van Tonder, and D. Vermeulen, 2014, Geo- logical evolution of low lying areas in Uganda: Impacts of climate variability on rock weathering and consequences on groundwater quality and availability-A review: Journal of Environmental Science and Water Resources, v. 3, no. 8, p. 163-183.

Okazaki, K., H. Noda, S. Uehara, and T. Shimamoto, 2014, Permeability, porosity and pore geometry evolution during compaction of Neogene sedimentary rocks: Journal of Structural Geology, v. 62, p. 1-12, doi: 10.1016/j.jsg.2013.12.010.

Olona, J., J. A. Pulgar, G. Ferna' ndez-Viejo, C. Lo' pez- Ferna' ndez, and J. M. Gonza' lez-Cortina, 2010, Weathering variations in a granitic massif and related geotechnical properties through seismic and electrical resistivity methods: Near Surface Geophysics, v. 8, no. 1750, p. 585-599.

P’an, C.-H., 1982, Petroleum in basement rocks: AAPG Bulletin, v. 66, no. 10, p. 1597-1643.

Parnell, J., 1988, Migration of biogenic hydrocarbons into granites; a review of hydrocarbons in British plutons: Marine and Petroleum Geology, v. 5, no. 4, p. 385-396, doi:10.1016/0264-8172(88)90032-3.

Petford, N., and K. McCaffrey, 2003, Hydrocarbons in crystalline rocks; an introduction, in N. Petford and K. J. W. McCaffrey, eds., Hydrocarbon in crystalline rocks: Geological Society, London, Special Publications 2003, v. 214, p. 1-5, doi:10.1144/GSL.SP.2003.214.01.01.”

Pique', A., A. Canals, F. Grandia, and D. A. Banks, 2008, Mesozoic fluorite veins in NE Spain record regional base metalrich brine circulation through basin and basement during extensional events: Chemical Geology, v. 257, no. 1-2, p. 139-152, doi:10.1016/j.chemgeo.2008.08.028.

Price, D. G., 2009, Engineering geology; principles and practice: Berlin, Springer-Verlag, 450 p.

Pros, Z., T. Lokajicek, R. Prikryl, A. Spicak, V. Vajdova, and K. Klima, 1998, Elastic parameters of West Bohemian granites under hydrostatic pressure: Pure and Applied Geophysics, v. 151, no. 2-4, p. 631-646, doi:10.1007

/s000240050134.

Reynolds, R. C. Jr., 1985, NEWMOD, a computer program

for the calculation of one-dimensional diffraction patterns of mixed-layered clays: Hanover, New Hampshire, R.C. Reynolds.

Salah, M. G., and A. S. Alsharhan, 1998, The Precambrian basement : A major reservoir in the rifted basin, Gulf of Suez: Journal of Petroleum Science and Engineering, v. 19, no. 3-4, p. 201-222.

Sarout, J., 2012, Impact of pore space topology on permeability, cut-off frequencies and validity of wave propagation the- ories: Pore space topology and wave propagation: Geo- physical Journal International, v. 189, no. 1, p. 481-492, doi:10.1111/j.1365-246X.2011.05329.x. 
Scheidegger, A. E., 1974, The physics of flow through porous media: Toronto, Ontario, Canada, University of Toronto Press, $353 \mathrm{p}$.

Schlueter, T., 2006, Geological atlas of Africa; with notes on stratigraphy, tectonics, economic geology, geohazards and geosites of each country: Berlin, Springer-Verlag, 307 p.

Sircar, A., 2004, Hydrocarbon production from fractured base- ment formations: Current Science, v. 87, no. 2, p. 147151. Slightam, C., 2014, Characterizing seismic-scale faults pre- and post-drilling; Lewisian Basement, West of Shetlands, UK, in G. H. Spence, J. Redfern, R. Aguilera, T. G. Bevan, J. W. Cosgrove, G. D. Couples, and J.-M. Daniel, eds., Advances in the study of fractured reservoirs: Geological Society, London, Special Publications 2014, v. 374, no. 1,

p. 311-331, doi:10.1144/SP374.6.

Smyth, J. R., and T. C. McCormick, 1995, Crystallographic

data for minerals, in T. J. Ahrens, ed., Mineral physics and crystallography: A handbook of physical constants: Washington, DC, American Geophysical Union, p. 1-17.

Soete, J., L. M. Kleipool, H. Claes, S. Claes, H. Hamaekers, S. Kele, M. Oezkul, A. Foubert, J. J. G. Reijmer, and R. Swennen, 2015, Acoustic properties in travertines and their relation to porosity and pore types: Marine and Petroleum Geology, v. 59, p. 320-335, doi:10.1016/j .marpetgeo.2014.09.004.

Stane`k, M., Y. Geraud, O. Lexa, P. Spacek, S. Ulrich, and M. Diraison, 2013, Elastic anisotropy and pore space geometry of schlieren granite: Direct 3-D measurements at high confining pressure combined with microfabric analysis: Geophysical Journal International, v. 194, no. 1, p. 383-394, doi:10.1093/gji/ggt053.

Straaten, H., 1977, Morphotectonic investigations along the Western Rift in the Masindi area, Bunyoro District, Uganda: Geologische Rundschau, v. 66, no. 1, p. 217-228, doi:10.1007/BF01989573.

Tamagawa, T., K. Tezuka, and N. Tsuchiya, 2012, Use of a computational fault-extraction process with calibrations to characterize a fractured basement reservoir, Yufutsu, Japan: AAPG Bulletin, v. 96, no. 12, p. 2275-2296, doi: $10.1306 / 05211211171$

Taylor, R., and K. Howard, 1998, Post-Palaeozoic evolu- tion of weathered landsurfaces in Uganda by tecton- ically controlled deep weathering and stripping:

Geomorphology, v. 25, p. 173-192, doi:10.1016

/S0169-555X(98)00040-3.

Taylor, R., and K. Howard, 2000, A tectono-geomorphic

model of the hydrogeology of deeply weathered crystalline rock: Evidence from Uganda: Hydro- geology Journal, v. 8, no. 3, p. 279-294, doi:10.1007 /s100400000069.

Tiab, D., and E. C. Donaldson, 2004, Petrophysics: Theory and practice of measuring reservoir rock and fluid transport properties: Boston, Massachusetts, Gulf Pro- fessional Publications, 889 p.

Trice, R., 2014, Basement exploration, West of Shetlands: Progress in opening a new play on the UKCS, in S. J. C. Cannon and D. Ellis, eds., Hydrocarbon explo- ration to exploration west of Shetlands: Geological So- ciety, London, Special Publications 2014, v. 397, p. 81-105, doi:10.1144/SP397.3.

Turner, B. F., R. F. Stallard, and S. L. Brantley, 2003, In- vestigation of in situ weathering of quartz diorite bedrock in the Rio Icacos basin, Luquillo Experimental Forest, Puerto Rico: Chemical Geology, v. 202, no. 3-4, p. 313-341, doi:10.1016/j.chemgeo.2003.05.001.

Van Brakel, J., 1975, Pore space models for transport phe- nomena in porous media-review and evaluation with special emphasis on capillary liquid transport: Powder Technology, v. 11, no. 3, p. 205-236, doi:10.1016/0032 5910(75)80049-0.

Vavra, C. L., J. G. Kaldi, and R. M. Sneider, 1992, Geological applications of capillary pressure; a review: AAPG Bul- letin, v. 76 , no. 6 , p. 840-850. 
Va'zquez, M., I. Abad, J. Jime'nez-Milla'n, F. T. Rocha, P. E. Fonseca, and H. I. Chamine', 2007, Prograde epi- zonal clay mineral assemblages and retrograde alteration in tectonic basins controlled by major strike-slip zones (W Iberian Variscan chain): Clay Minerals, v. 42, no. 1, p. 109-128, doi:10.1180/claymin.2007.042.1.08.

Va'zquez, P., F. J. Alonso, R. M. Esbert, and J. Ordaz, 2010, Ornamental granites: Relationships between p-waves velocity, water capillary absorption and the crack net- work: Construction \& Building Materials, v. 24, p. 2536-2541, doi:10.1016/j.conbuildmat.2010.06.002.

Vidal Roman'ı, J., and C. Twidale, 1999, Sheet fractures, other stress forms and some engineering implications: Geomorphology, v. 31, no. 1-4, p. 13-27, doi:10.1016 /S0169-555X(99)00070-7.

Virransalo,P.,P.Härma“,J.Pokki,T.Manninen,M.Lehtonen, and T. Koistinen, 2012, Geological map of Uganda, Hoima: Entebbe, Uganda, Department of Geological Survey and Mines, sheet NA-36-9, scale 1:250,000, 1 sheet.

Vollbrecht, A., H. Duerrast, J. Kraus, and K. Weber, 1994, Paleostress directions deduced from microcrack fabrics in KTB core samples and granites from the surrounding area: Scientific Drilling, v. 4, no. 5-6, p. 233-241.

Vollbrecht, A., S. Rust, and K. Weber, 1991, Development of microcracks in granites during cooling and uplift: Examples from the Variscan basement in NE Bavaria, Germany: Journal of Structural Geology, v. 13, no. 7, p. 787-799, doi:10.1016/0191-8141(91)90004-3.

Walsh, J. B., and W. F. Brace, 1984, The effect of pressure on porosity and the transport properties of rock: Journal of Geophysical Research, v. 89, no. B11, p. 9425-9431, doi: 10.1029/JB089iB11p09425.

Wang, H. F., B. P. Bonner, S. R. Carlson, B. J. Kowallis, and H. C. Heard, 1989, Thermal stress cracking in granite: Journal of Geophysical Research, v. 94, no. B2), p. 1745-1758, doi:10.1029/JB094iB02p01745.

Wang, H. F., and G. Simmons, 1978, Microcracks in crys- talline rock from 5.3-km depth in the Michigan Basin: Journal of Geophysical Research, v. 83, no. B12, p. 5849-5856, doi:10.1029/JB083iB12p05849.

Wang, J., C. Zou, J. Jin, and R. Zhu, 2011, Characteristics and controlling factors of fractures in igneous rock reservoirs: Petroleum Exploration and Development, v. 38, no. 6, p. 708-715, doi:10.1016/S1876-3804(12)60005-6

Washburn, E. W., 1921, The dynamics of capillary flow: Physical Review, v. 17, no. 3, p. 273-283, doi:10.1103 /PhysRev.17.273.

Westerhof,A.B.,P.Härmä,E.Isabirye,E.Katto,T.Koistinen, E. Kuosmanen, T. Lehto, et al., 2014, Geology and geodynamic development of Uganda with explanation of

the 1:1,000,000-scale geological map: Espoo, Finland, Geological Survey of Finland Special Paper 55, 387 p. Wright, E. P., 1992, The hydrogeology of crystalline basement aquifers in Africa; introduction, in E. P. Wright and W. G. Burgess, eds., The hydrocarbon of crystalline basement aquifers in Africa: Geological Society, London, Special Publications 1992, v. 66, p. 1-27, doi:10.1144/GSL.SP.1992.066.01.01.

Yasar, E., and Y. Erdogan, 2004, Correlating sound velocity with the density, compressive strength and Young's modulus of carbonate rocks: International Journal of Rock Mechanics and Mining Sciences, v. 41, no. 5, p. 871-875, doi:10.1016/j.ijrmms.2004.01.012.

Younes, A. I., T. Engelder, and W. Bosworth, 1998, Fracture distribution in faulted basement blocks; Gulf of Suez, Egypt, in M. P. Coward, T. S. Daltaban, and H. Johnson, eds., Structural geology in reservoir characterization: Geological Society, London, Special Publications 1998, v.127,p.167-190,doi:10.1144/GSL.SP.1998.127.01.13.

Zinszner, B., and F. M. Pellerin, 2007, A geoscientist's guide to petrophysics: Paris, Editions Technip, 384 p. 
Figure 1. Hydrogeological model of a typical weathering profile developed upon crystalline basement rocks under hot and humid climatic conditions. (A, B) Textural description of the typical geomorphic units (modified from Chilton and Foster, 1995). (C) Typical hydraulic properties variations along the weathering profile (from Acworth, 1987).

\section{(A)}

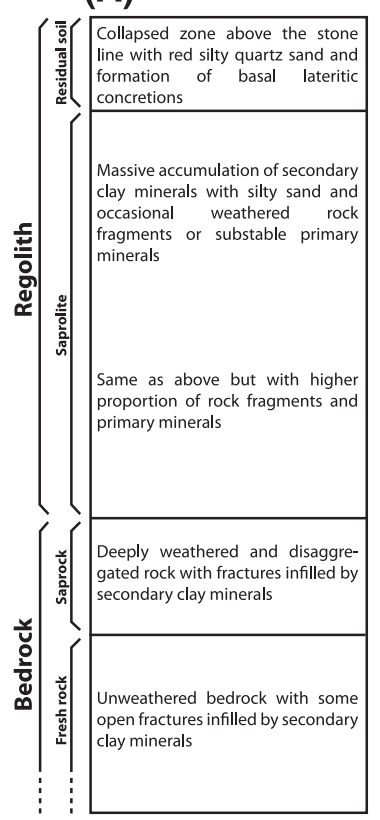

(B)

(C)

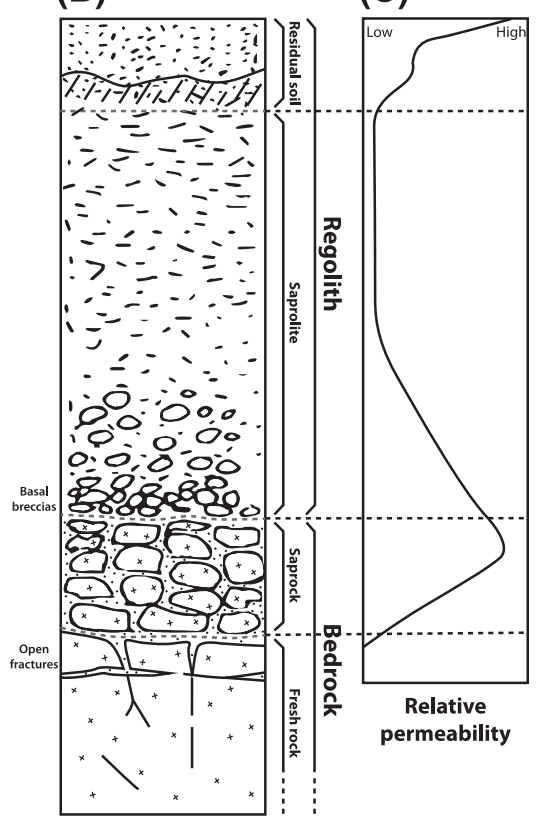

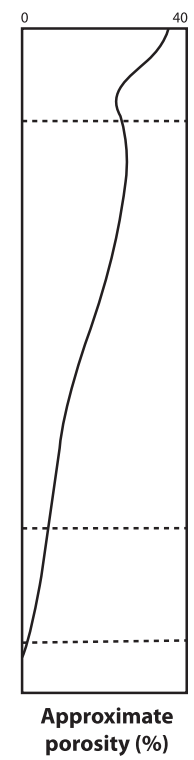




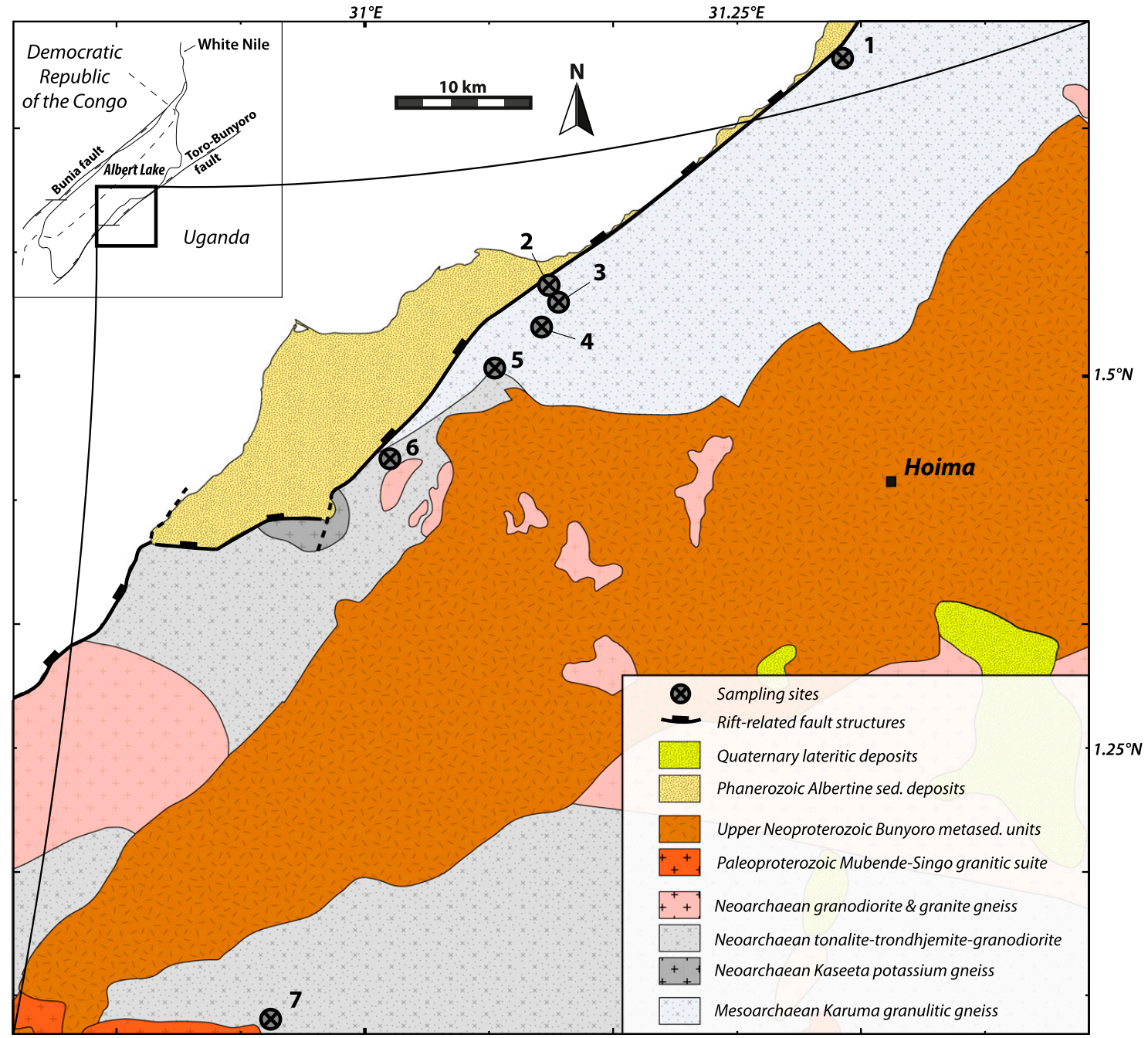

Figure 2. Geological map of the study area and sampling sites (modified from Virransalo et al., 2012). 


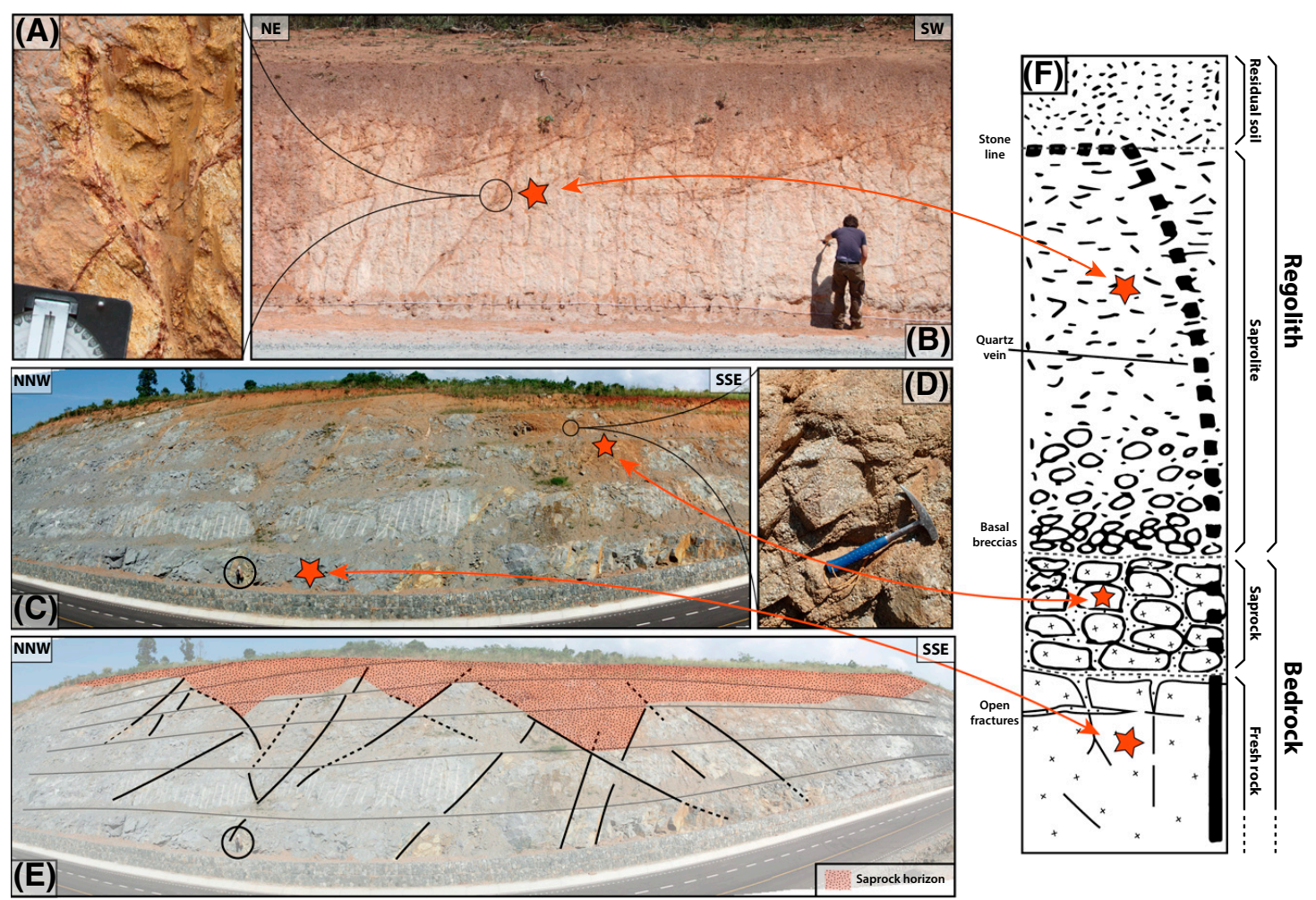

Figure 3. (A, B) Highly weathered crystalline basement on site 5. (C) Road cross section in the vicinity of site 6 with basal subfresh to top weathered basement facies. (D) Moderately weathered basement. (E) Structural interpretation of (C), showing the brittle structure control on the development of the weathering horizons. (F) Sample locations along the typical crystalline basement weathering profile (modified from Chilton and Foster, 1995).

Table 1. Standard Terminology of Rock Weathering Grade Description

\begin{tabular}{|c|c|c|}
\hline Weathering Grade Description & Weathering Grade Number & Mass Rock Description \\
\hline Fresh & I & No visible change of weathering. \\
\hline Slightly weathered (SW) & II & $\begin{array}{l}\text { Slight changes in color, especially close to the } \\
\text { discontinuity planes, which may contain a thin filling } \\
\text { of altered material. }\end{array}$ \\
\hline Moderately weathered (MW) & III & $\begin{array}{l}\text { Color change extends. Discontinuity places may } \\
\text { contain fillings of altered material. Partial grain } \\
\text { boundaries opening. Specimen is considerably } \\
\text { weakened but cannot be broken by hand. }\end{array}$ \\
\hline Highly weathered (HW) & IV & $\begin{array}{l}\text { Color change extends to most of the rock. Grain } \\
\text { separation has occurred with altered material. Rock } \\
\text { is considerably weakened and friable; large pieces } \\
\text { can be broken by hand. }\end{array}$ \\
\hline Completely weathered (CW) & V & $\begin{array}{l}\text { Total color change from the initial color. Rock texture is } \\
\text { partly preserved, and grains are completely } \\
\text { separated by altered material. Massive weakening; } \\
\text { rock disintegrates in water. }\end{array}$ \\
\hline
\end{tabular}

Modified from Ehlen (2002) and Price (2009). 
Table 2. Sample Weathering Grade Classification, Site Number, and Location

\begin{tabular}{|c|c|c|c|c|}
\hline Sample & Weathering Grade & Site & Sample GPS Coordinates (WGS84, Decimal Degrees) & Altitude (m) \\
\hline ug 13.38 & $\mathrm{~V}(\mathrm{CW})$ & 7 & E $030.926747^{\circ} ; \mathrm{N} 01.059395^{\circ}$ & 1252 \\
\hline ug13.39 & $\mathrm{V}(\mathrm{CW})$ & 7 & E $030.926747^{\circ} ; \mathrm{N} 01.059395^{\circ}$ & 1250 \\
\hline ug 13.35 & $\mathrm{~V}(\mathrm{CW})$ & 5 & E $031.087298^{\circ} ; \mathrm{N} 01.507965^{\circ}$ & 1062 \\
\hline ug13.34 & $\mathrm{V}(\mathrm{CW})$ & 5 & E $031.087298^{\circ} ; \mathrm{N} 01.507965^{\circ}$ & 1061 \\
\hline ug13.18 & III (MW) & 3 & E $031.122827^{\circ} ; \mathrm{N} 01.558291^{\circ}$ & 953 \\
\hline ug14.49 & III (MW) & 1 & E $031.319332^{\circ} ; \mathrm{N} 01.720703^{\circ}$ & 777 \\
\hline ug14.50 & III (MW) & 1 & E $031.319332^{\circ} ; \mathrm{N} 01.720703^{\circ}$ & 778 \\
\hline ug 13.06 & II (SW) & 2 & E $031.117771^{\circ} ; \mathrm{N} 01.564189^{\circ}$ & 822 \\
\hline ug13.07 & II (SW) & 2 & E $031.117765^{\circ} ; \mathrm{N} 01.564158^{\circ}$ & 822 \\
\hline ug 13.17 & II (SW) & 3 & E $031.123382^{\circ} ; \mathrm{N} 01.557782^{\circ}$ & 963 \\
\hline ug 13.19 & II (SW) & 3 & E $031.122719^{\circ} ; \mathrm{N} 01.558486^{\circ}$ & 950 \\
\hline ug 13.28 & $\mathrm{I}(\mathrm{F})$ & 6 & E $031.011146^{\circ} ; \mathrm{N} 01.437570^{\circ}$ & 1052 \\
\hline ug 13.27 & $\mathrm{I}(\mathrm{F})$ & 4 & E $031.114850^{\circ} ; \mathrm{N} 01.53000^{\circ}$ & 985 \\
\hline
\end{tabular}

Abbreviations: CW = completely weathered; F = fresh; GPS = global positioning system; MW = moderately weathered; SW = slightly weathered; WGS84 = world geodetic system 1984. 


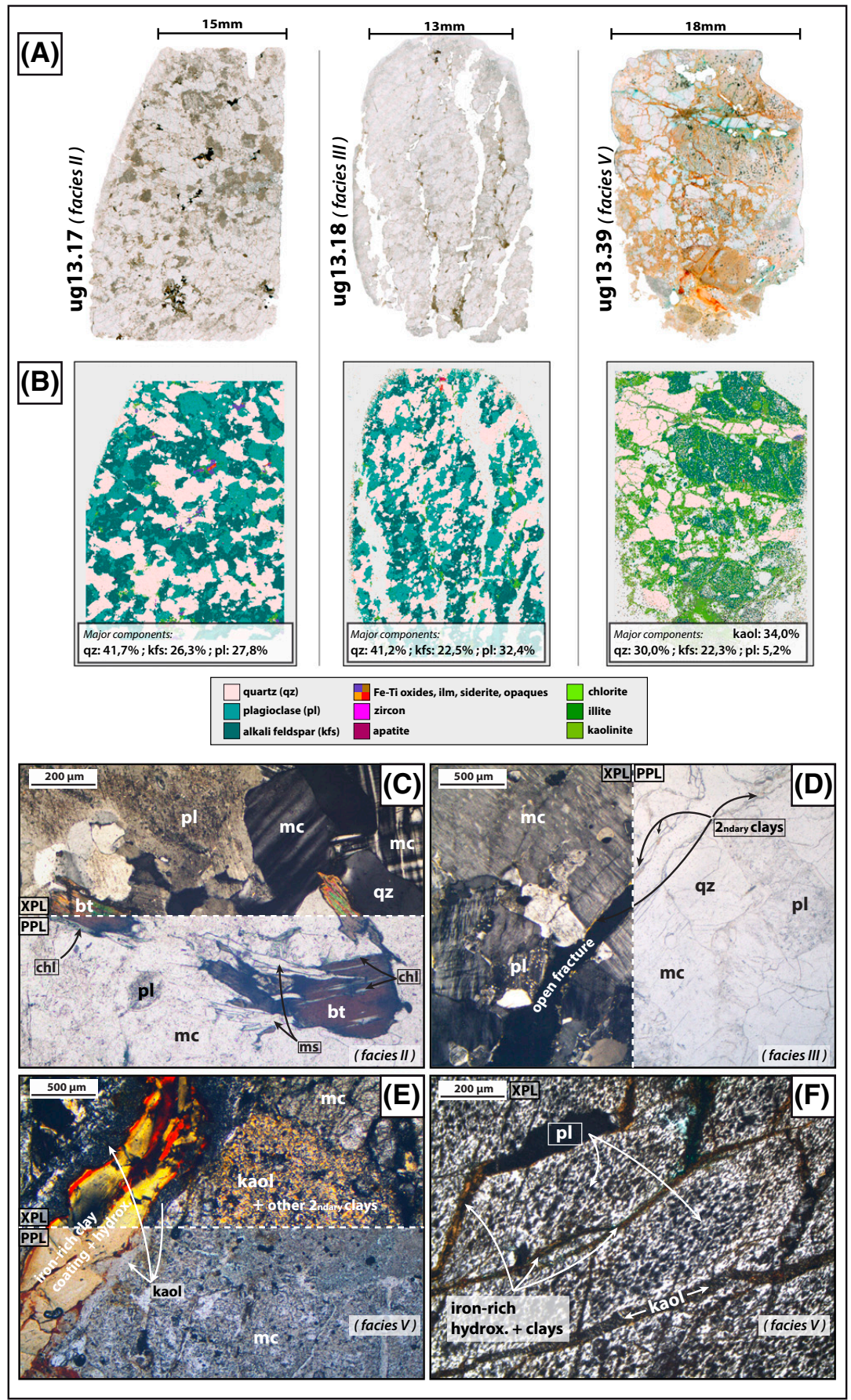

Figure 4. (A) Thin section scans of three different weathering grade samples. (B) Mineralogical cartography and quantification of thin sections in (A) from quantitative evaluation of minerals by scanning electron microscopy analysis. Proportion of major components $(>5 \%)$ is given. (C) Granitic subequigranular texture of subfresh sample. Microcline (mc), quartz (qz), and muscovite (ms) remain fresh. Alteration of plagioclase (pl) occurred, and biotite (bt) is partly replaced by chlorite (chl). (D) Development of significant open joints in intermediately weathered sample, with localized development of secondary clay material. (E) Completely weathered sample showing high crack density through $\mathrm{mc}$, kaolinite (kaol)-rich clay aggregates, and structures with massive iron-rich clay coating and hydroxides (hydrox.). (F) Plagioclase organized minute residue texture and iron-rich material fracture infilling. $\mathrm{kfs}=$ alkali feldspar; PPL = plane-polarized light; $\mathrm{XPL}=$ cross-polarized light. 
Table 3. Semiquantitative Proportions from X-Ray Diffraction Analyses of the Mineral Phases of the Bulk Rock Powder and Clays in the Less Than $2 \mu \mathrm{m}$ Fraction of the Bulk Rock Powder

\begin{tabular}{|c|c|c|c|c|c|c|c|c|c|c|c|}
\hline \multirow[b]{2}{*}{ Sample } & \multirow[b]{2}{*}{ Weathering Grade } & \multicolumn{6}{|c|}{ Bulk Rock Powder (\%) } & \multicolumn{4}{|c|}{ Clay in the Less Than $2 \mu \mathrm{m}$ Fraction (\%) } \\
\hline & & $\mathrm{qz}$ & k-fs & $\mathrm{pl}$ & bt & $\mathrm{ms}$ & kaol & Smectite & $\mathrm{Sm} / \mathrm{Chl}$ & Illite & Kaolinite \\
\hline ug 13.38 & V (CW) & 75 & 19 & & & & 6 & 5 & & 5 & 90 \\
\hline ug13.39 & V (CW) & & & & & & & & & & \\
\hline ug13.35 & V (CW) & 72 & 21 & & & 3 & 4 & & & 25 & 75 \\
\hline ug13.34 & V (CW) & 67 & 29 & & & & 4 & & & 10 & 90 \\
\hline ug13.18 & III (MW) & 59 & 19 & 20 & & 2 & & 20 & & 55 & 25 \\
\hline ug14.49 & III (MW) & & & & & & & & & & \\
\hline ug14.50 & III (MW) & & & & & & & & & & \\
\hline ug13.06 & II (SW) & 55 & 16 & 27 & & 2 & & 25 & 20 & 55 & \\
\hline ug13.07 & II (SW) & 56 & 15 & 26 & 2 & 1 & & & & & \\
\hline ug13.17 & II (SW) & 52 & 10 & 34 & & 4 & & 40 & 20 & 30 & 10 \\
\hline ug13.19 & II (SW) & 49 & 12 & 33 & 2 & 4 & & & & & \\
\hline ug 13.28 & $I(F)$ & 59 & 24 & 17 & & & & 45 & 55 & & \\
\hline ug13.27 & $\mathrm{I}(\mathrm{F})$ & & & & & & & & & & \\
\hline
\end{tabular}

Abbreviations: $\mathrm{bt}=$ biotite; $\mathrm{CW}=$ completely weathered; $\mathrm{F}=$ fresh; $\mathrm{kaol}=$ kaolinite; $\mathrm{k}$-fs = K-feldspar; $\mathrm{ms}=$ muscovite; $\mathrm{MW}=$ moderately weathered; $\mathrm{pl}=\mathrm{plagioclase} ; \mathrm{qz}=$ quart; $\mathrm{Sm} / \mathrm{Chl}=$ smectite/chlorite; $\mathrm{SW}=$ slightly weathered.

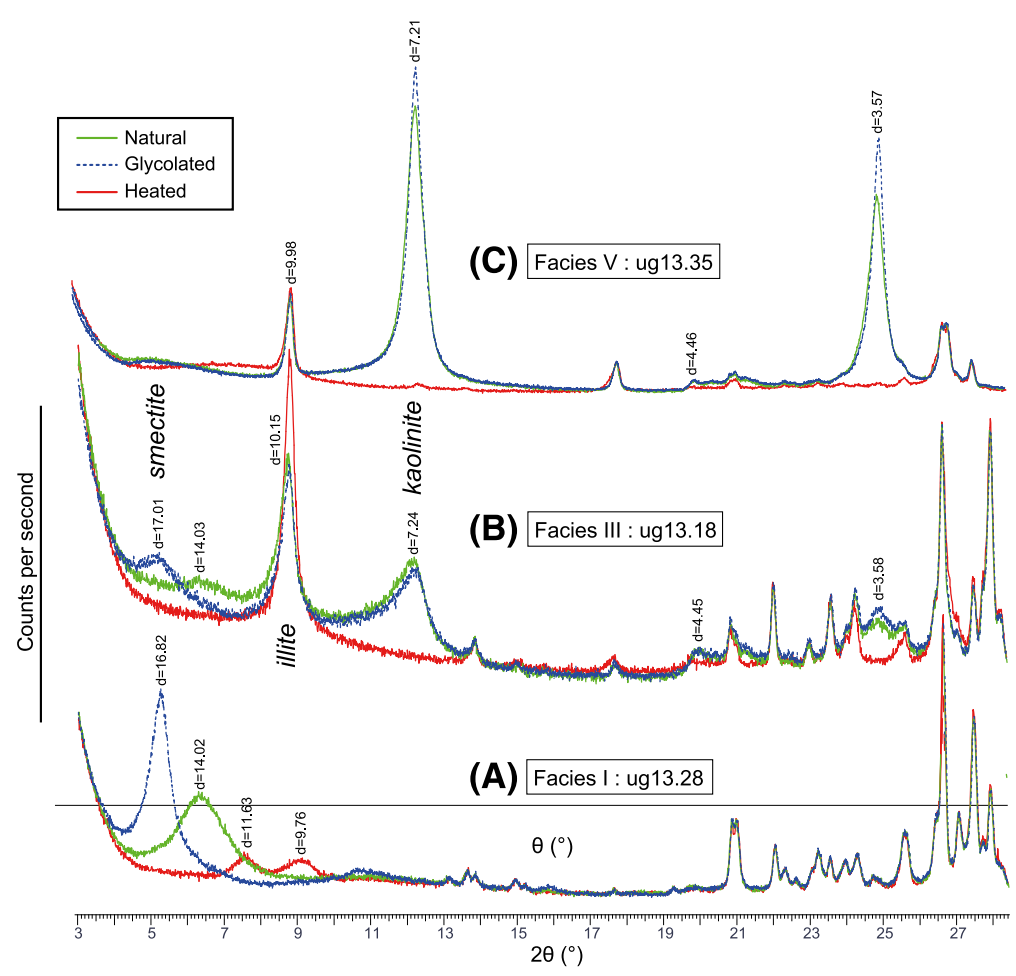

Figure 5. The x-ray diffractograms of three different weathering grade samples. (A) Facies I, sample ug13.28. (B) Facies III, sample ug13.18. (C) Facies V, sample ug 13.35, obtained on less than $2 \mu \mathrm{m}$ fraction of the bulk rock powder. Diffractogram scales are diffraction intensity (in counts per second) and incident diffraction angle $2 \theta$ (in degrees). Color spectra for each sample represent analyses on natural power (green), powder exposed to ethylene glycol (blue), and powder heated at $500^{\circ} \mathrm{C}$ (red), based on the analytical protocol proposed by Holtzapffel (1985). 

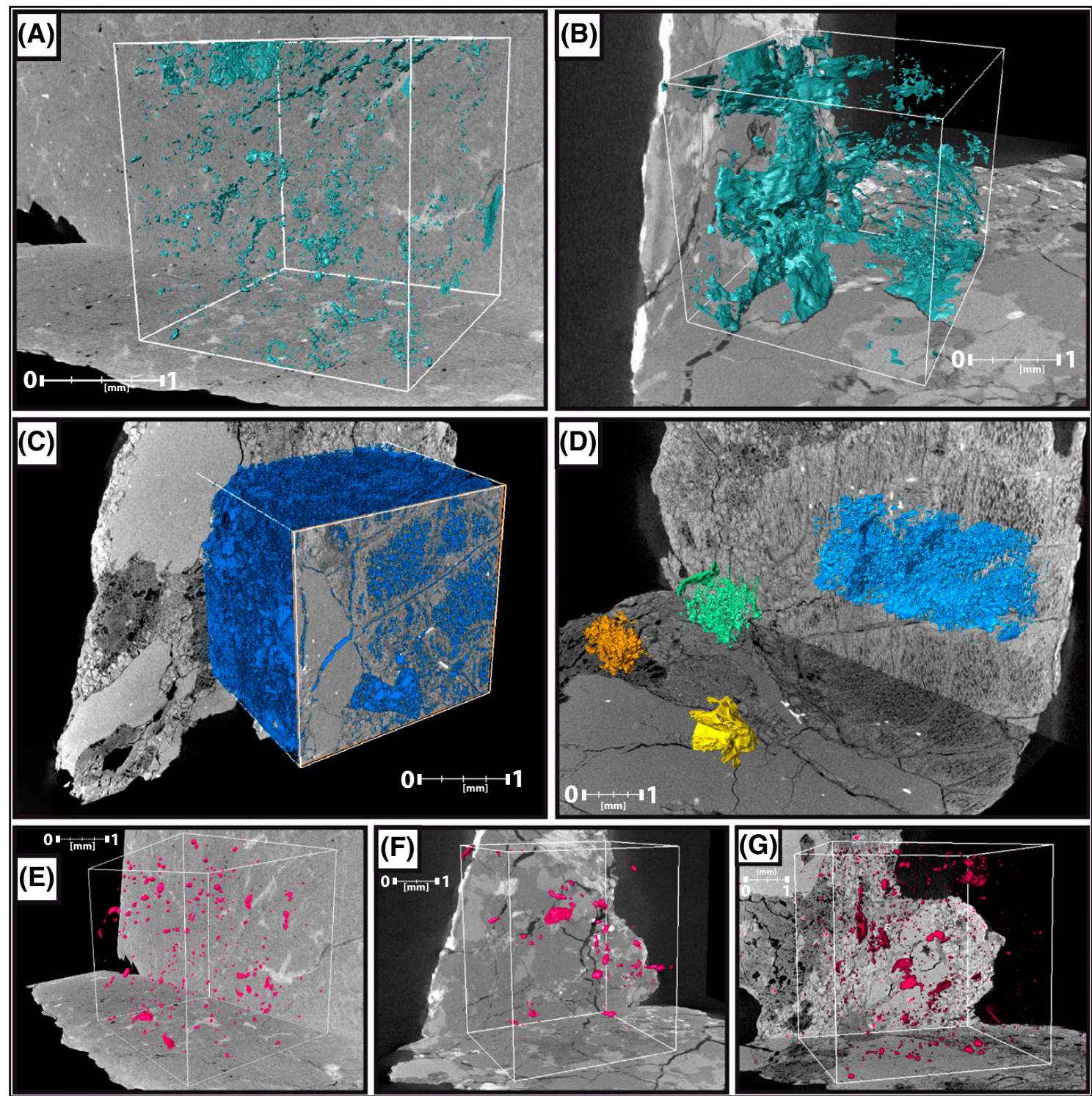

Figure 6. Three-dimensional (3-D) distribution of porosity or dense mineral phases within computed volume of different weathering grade samples, from x-ray tomography scanning. The 3-D distributions of the porosity (turquoise) of the (A) ug13.06 (facies II) and (B) ug13.18 (facies III) samples. (C) The 3-D distribution of the total porosity (blue) of the ug13.39 (facies V). (D) The 3-D distribution of the porosity of different selected mineral phases (fissured quart porosity in yellow, plagioclase residues porosity in blue, kaolinite aggregates porosity in orange, and polyphased weathering mixture porosity in green). The 3-D distributions of the highest-density elements (purple) of the three (E) ug13.06, (F) ug13.18, and (G) ug13.39 samples. 
(A)

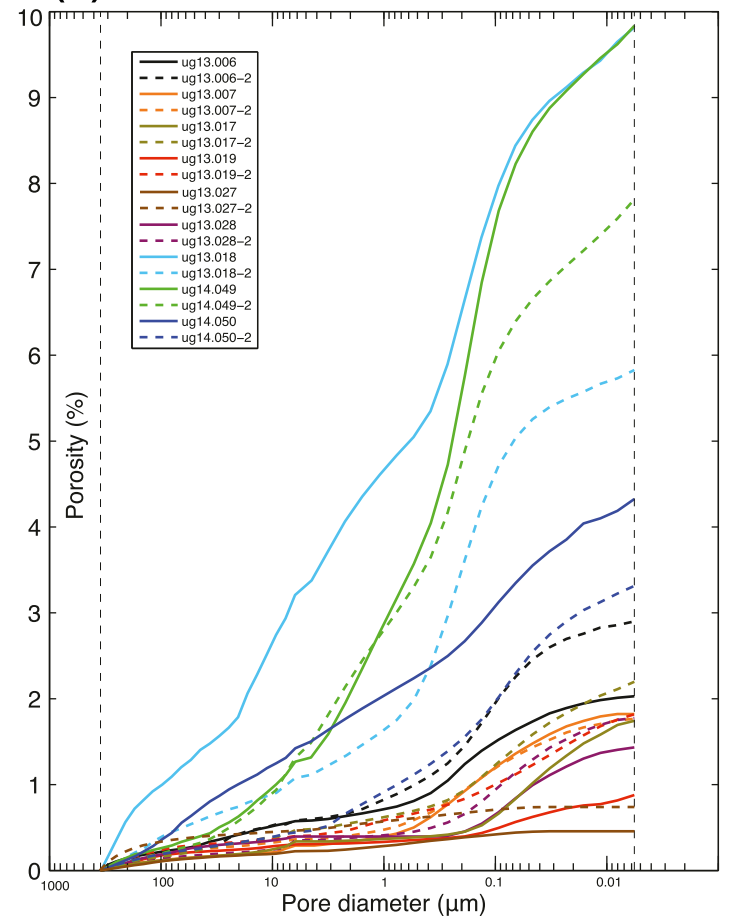

(B)

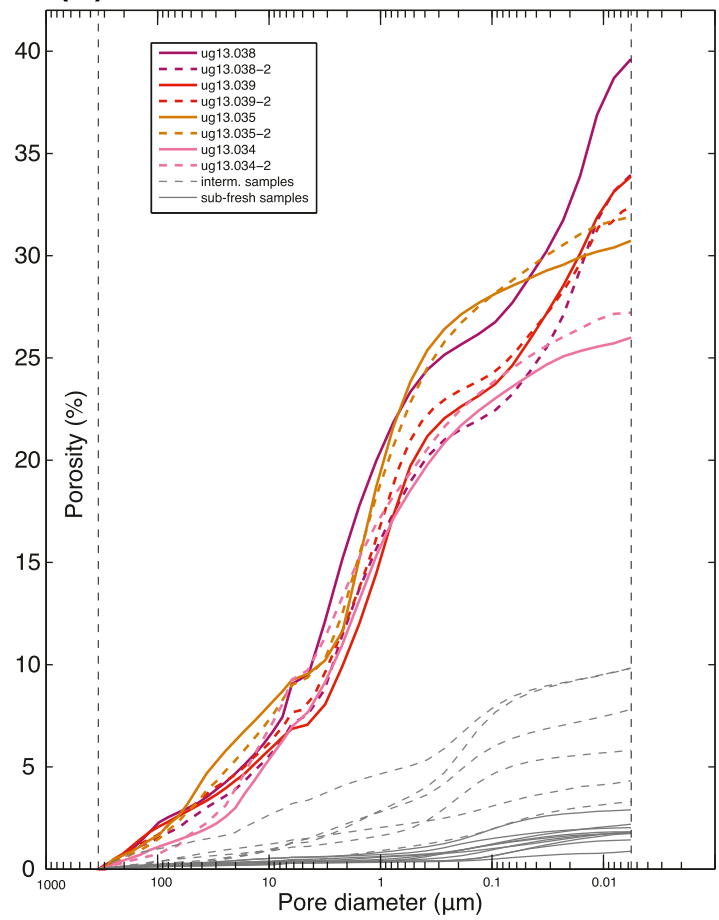

Figure 7. Intrusion curves from the mercury intrusion porosimetry tests of $(A)$ the low and intermediate samples and $(B)$ the completely weathered samples (gray curves are those of the low and intermediate samples of $[A]$ ). 
Table 4. Results of the Mercury Intrusion Porosimetry Tests Carried out on Two Fragments per Sample

\begin{tabular}{cccccc}
\hline Sample & Weathering Grade & Porosity $(\%)$ & $\begin{array}{c}\text { Skeletal Density } \\
\left(\mathrm{g} / \mathrm{cm}^{3}\right)\end{array}$ & $\begin{array}{c}\text { Bulk Density } \\
\left(\mathrm{g} / \mathrm{cm}^{3}\right)\end{array}$ & $\begin{array}{c}\text { Median Pore } \\
\text { Throat Size }(\mu \mathrm{m})\end{array}$ \\
\hline ug13.38-1 & V (CW) & 39.62 & 2.60 & 1.57 & 1.13 \\
ug13.38-2 & V (CW) & 33.96 & 2.48 & 1.64 & 0.85 \\
ug13.39-1 & V (CW) & 33.88 & 2.45 & 1.62 & 0.81 \\
ug13.39-2 & V (CW) & 32.39 & 2.59 & 1.75 & 1.09 \\
ug13.35-1 & V (CW) & 30.73 & 2.54 & 1.76 & 1.53 \\
ug13.35-2 & V (CW) & 31.90 & 2.54 & 1.73 & 1.46 \\
ug13.34-1 & V (CW) & 26.00 & 2.60 & 1.92 & 2.10 \\
ug13.34-2 & V (CW) & 27.22 & 2.52 & 1.83 & 0.69 \\
ug13.18-1 & III (MW) & 9.81 & 2.64 & 2.38 & 0.28 \\
ug13.18-2 & III (MW) & 5.83 & 2.64 & 2.49 & 0.25 \\
ug14.49-1 & III (MW) & 8.93 & 2.60 & 2.36 & 0.32 \\
ug14.49-2 & III (MW) & 7.81 & 2.52 & 2.32 & 0.69 \\
ug14.50-1 & III (MW) & 4.33 & 2.59 & 2.48 & 0.16 \\
ug14.50-2 & III (MW) & 3.31 & 2.62 & 2.53 & 0.29 \\
ug13.06-1 & II (SW) & 2.03 & 2.62 & 2.56 & 0.25 \\
ug13.06-2 & II (SW) & 3.22 & 2.65 & 2.57 & 0.20 \\
ug13.07-1 & II (SW) & 1.82 & 2.62 & 2.58 & 0.22 \\
ug13.07-2 & II (SW) & 1.77 & 2.64 & 2.59 & 0.06 \\
ug13.17-1 & II (SW) & 1.74 & 2.65 & 2.60 & 0.13 \\
ug13.17-2 & II (SW) & 2.20 & 2.63 & 2.57 & 0.13 \\
ug13.19-1 & II (SW) & 0.88 & 2.66 & 2.64 & 0.14 \\
ug13.19-2 & II (SW) & 1.82 & 2.64 & 2.59 & 0.09 \\
ug13.28-1 & I (F) & 1.43 & 2.61 & 2.57 & 0.11 \\
ug13.28-2 & I (F) & 1.78 & 2.62 & 2.57 & \\
ug13.27-1 & I (F) & 0.46 & 2.63 & 2.63 & \\
ug13.27-2 & I (F) & 0.58 & 2.65 & & \\
\hline
\end{tabular}

The ug13.27 sample's porosity is below the device's resolution level. The very low connected porosity value is valid, but other parameters cannot be calculated. Abbreviations: $\mathrm{CW}=$ completely weathered; $\mathrm{F}=$ fresh; $\mathrm{MW}=$ moderately weathered; $\mathrm{SW}=$ slightly weathered. 

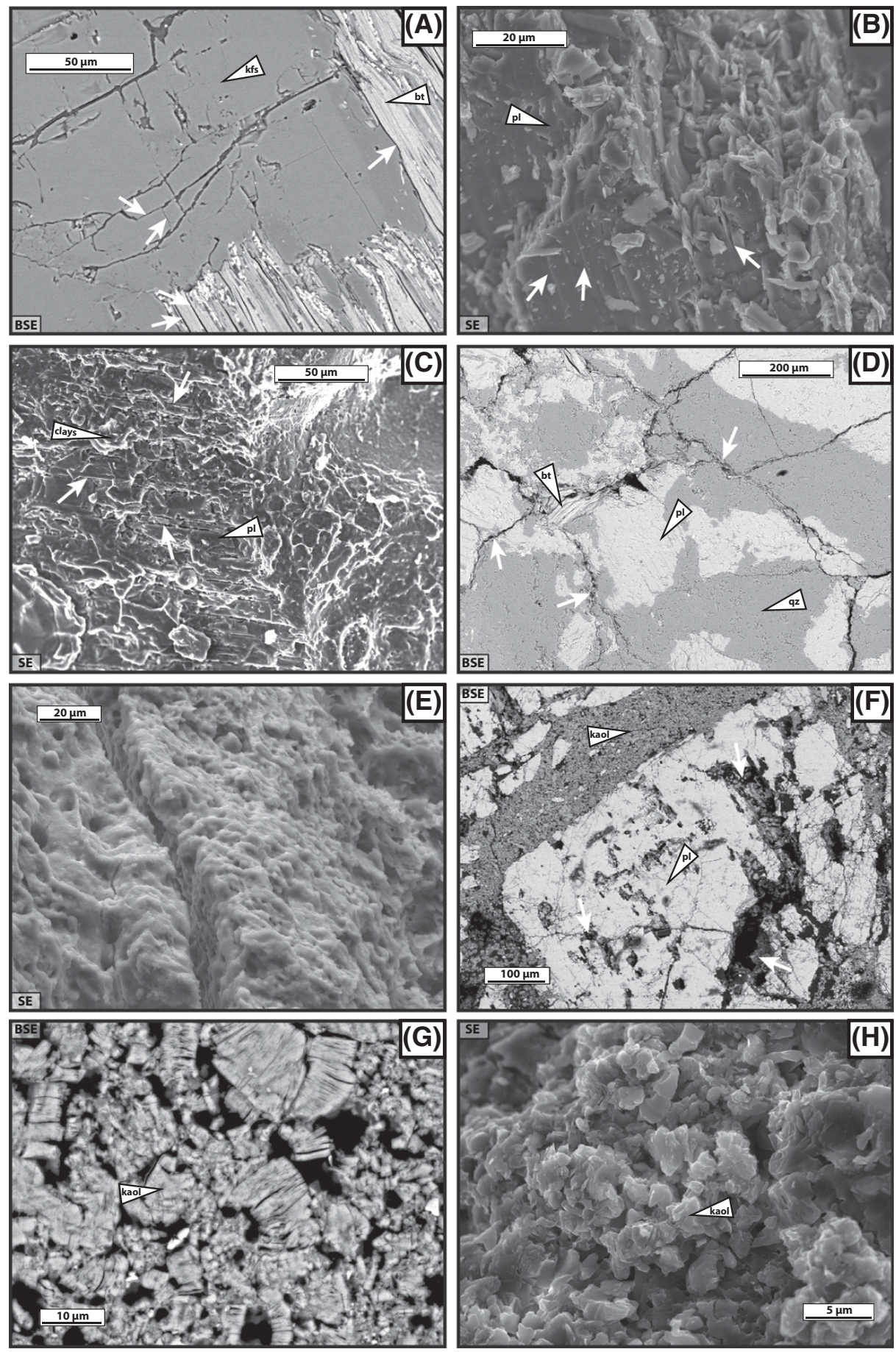

Figure 8. Scanning electron microscopic images of different weathering grade samples, carried out on both fragment and thin section samples. (A, B) Examples of planar porous structures in subfresh samples (facies I-II, thin section and fragment) (indicated by white arrows): alkali feldspar (kfs) intragrain microcrack structures developed according to mineral crystallographic planes, biotite (bt) intragrain 
Table 5. Results of the Skeletal Density (Measured with Helium Pycnometer), Permeability, and P-Wave Propagation Velocity Measurements

\begin{tabular}{lcccrr}
\hline Sample & Weathering Grade & Skeletal Density $\left(\mathrm{g} / \mathrm{cm}^{3}\right)$ & Permeability $(\mathrm{md})$ & $V_{p}(\mathrm{~m} / \mathrm{s})$ & $\mathrm{G}$ Factor \\
\hline ug13.038 & V (CW) & 2.645 & 118 & 1041 & 220.0 \\
ug13.039 & V (CW) & 2.643 & 939 & 933 & 9.2 \\
ug13.035 & V (CW) & 2.651 & 23.9 & 953 & 660.5 \\
ug13.034 & V (CW) & 2.617 & 173 & 1291 & 116.4 \\
ug13.018 & III (MW) & 2.638 & 35 & 2413 & 2.5 \\
ug14.049 & III (MW) & 2.607 & 387 & 2565 & 0.2 \\
ug14.050 & III (MW) & 2.613 & 1.55 & 3586 & 7.4 \\
ug13.006 & II (SW) & 2.629 & 3.11 & 3637 & 6.1 \\
ug13.007 & II (SW) & 2.615 & 0.121 & 3527 & 120.1 \\
ug13.017 & II (SW) & 2.656 & $2.31 \times 10^{-4}$ & 4556 & $21,327.9$ \\
ug13.019 & II (SW) & 2.657 & $2.81 \times 10^{-3}$ & 4800 & 588.0 \\
ug13.028 & I (F) & 2.615 & $3.65 \times 10^{-4}$ & 5483 & $10,990.4$ \\
ug13.027 & I (F) & 2.623 & $1.99 \times 10^{-4}$ & 5144 & \\
\hline
\end{tabular}

$G$ values calculated from the different petrophysical parameters (see section Relationships between Porosity and Bulk Density, P-Wave Propagation Velocity, and Permeability for more information).

Abbreviation: $\mathrm{CW}=$ completely weathered; $\mathrm{F}=$ fresh; $\mathrm{MW}=$ moderately weathered; $\mathrm{SW}=$ slightly weathered; $V_{p}=\mathrm{P}$-wave propagation velocity.
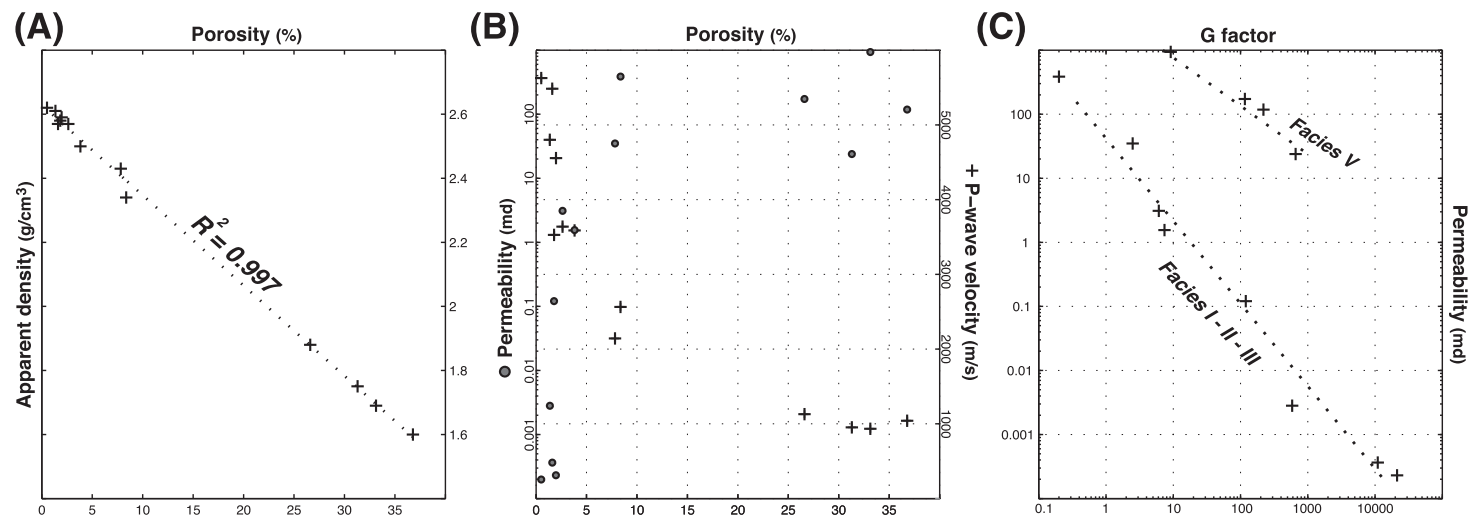

Figure 9. Relationship between the different petrophysical properties results. (A) Linear relationship between samples porosity and apparent density with weathering. (B) Nonlinear permeability and P-wave propagation velocity variations with porosity. (C) Relationship between the calculated $\mathrm{G}$ factor and the permeability of the different weathered samples. Two different trends are identified, for the fresh to intermediately weathered samples (facies I-III) and for the highly weathered samples (facies IV-V), indicated by two black dashed lines. 


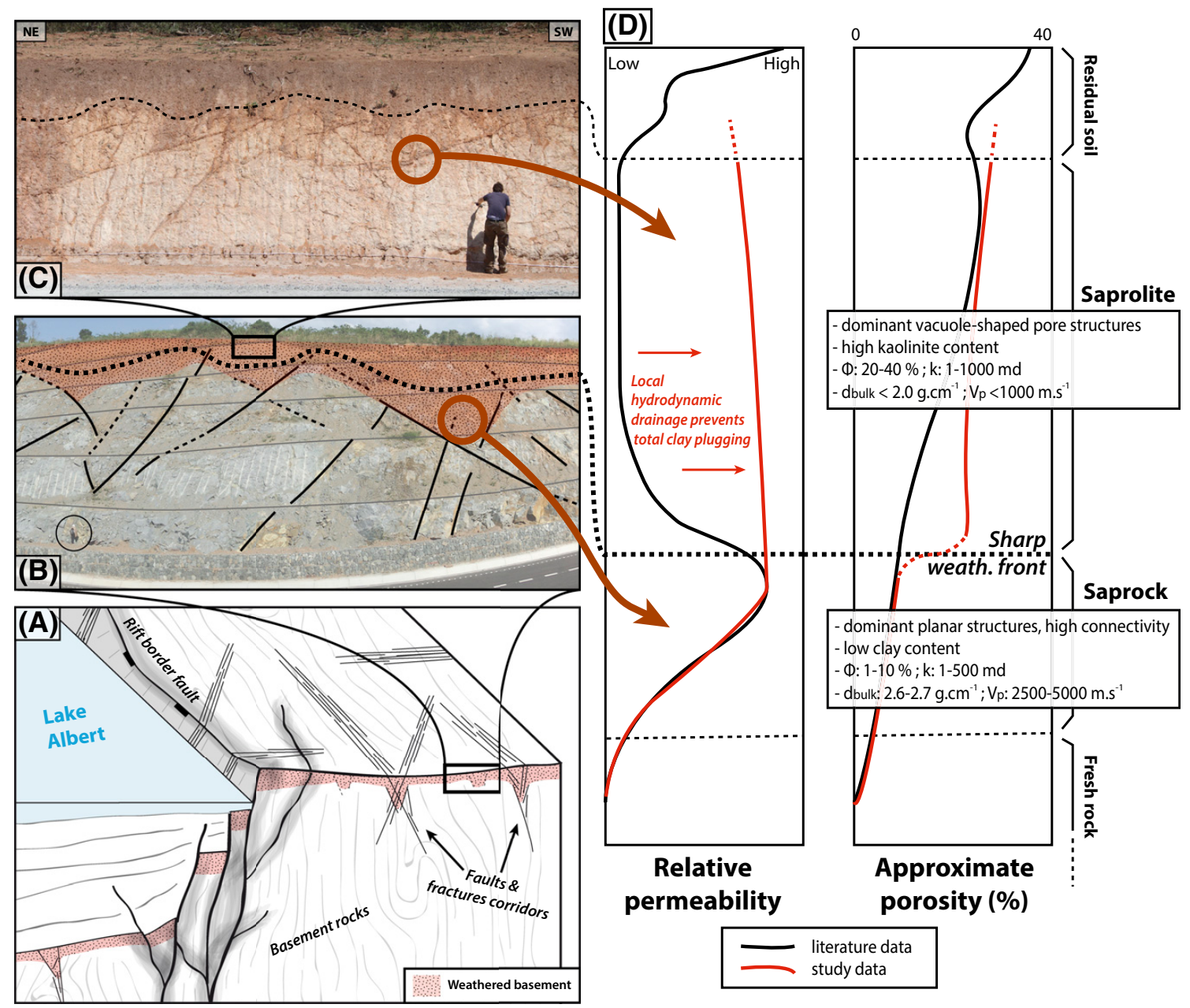

Figure 10. Conceptual organization of the crystalline basement weathering in western Uganda. (A) Large-scale three-dimensional block model of western Uganda area with weathering profile preserved on the rift shoulder and within the basin. (B) Road cross section with basal subfresh to weathered basement facies and structural control on the development of the weathering horizons. The sharp transition between the saprock and saprolite facies is schematically drawn in this weathered medium. (C) Example of saprolite facies outcrop schematically placed at the top of the outcrop in (B). (D) Synthesis of the mineralogical and petrophysical properties of both saprock and saprolite units of the weathering profile. Comparison of the hydraulic properties variations along the weathering profile of this study and of a typical profile described in the literature (from Acworth, 1987). $d_{\text {bulk }}=$ bulk density; $k=$ permeability; $\varphi=$ porosity; $V_{p}=$ P-wave propagation velocity. 